\title{
Rainfall induced landslides in December 2004 in south-western Umbria, central Italy: types, extent, damage and risk assessment
}

\author{
M. Cardinali ${ }^{1}$, M. Galli ${ }^{1}$, F. Guzzetti ${ }^{1}$, F. Ardizzone $^{1}$, P. Reichenbach ${ }^{1}$, and P. Bartoccini ${ }^{2}$ \\ ${ }^{1}$ CNR - IRPI, via Madonna Alta 126, 06128 Perugia, Italy \\ ${ }^{2}$ Consultant, via Vittorio Veneto 14/A, 06050 Papiano, Italy
}

Received: 13 September 2005 - Revised: 11 January 2006 - Accepted: 22 February 2006 - Published: 20 April 2006

\begin{abstract}
The autumn of 2004 was particularly wet in Umbria, with cumulative rainfall in the period from October to December exceeding $600 \mathrm{~mm}$. On 4-6 December and on 2527 December 2004, two storms hit the Umbria Region producing numerous landslides, which were abundant near the town of Orvieto where they affected volcanic deposits and marine sediments. In this work, we document the type and abundance of the rainfall-induced landslides in the Orvieto area, in south-western Umbria, we study the rainfall conditions that triggered the landslides, including the timing of the slope failures, we determine the geotechnical properties of the failed volcanic materials, and we discuss the type and extent of damage produced by the landslides. We then use the recent event landslide information to test a geomorphological assessment of landslide hazards and risk prepared for the village of Sugano, in the Orvieto area. Based on the results of the test, we update the existing landslide hazards and risk scenario for extremely rapid landslides, mostly rock falls, and we introduce a new landslide scenario for rapid and very rapid landslides, including soil slides, debris flows and debris avalanches.
\end{abstract}

\section{Introduction}

The autumn and early winter of 2004 were particularly wet in the Umbria Region of central Italy. Repeated rainfall episodes and high intensity storms resulted in a cumulative rainfall in the period from October to December exceeding $600 \mathrm{~mm}$. On 4-6 December and on 25-27 December 2004, two severe storms hit the Umbria Region. The rainfall events produced numerous landslides, which were particularly abundant along the Tiber River valley, E and SE of Todi, and in the Orvieto area (Fig. 1).

Correspondence to: M. Cardinali

(m.cardinali@irpi.cnr.it)
Through reconnaissance field surveys carried out after the rainfall events, we mapped 486 landslides in Umbria, for a total landslide area of about $9.40 \times 10^{5} \mathrm{~m}^{2}$, and an estimated total landslide volume of about $1.7 \times 10^{6} \mathrm{~m}^{3}$. Average landslide density was 1.7 slope failures per square kilometre, and locally exceeded 12 landslides per square kilometre. The rainfall induced landslides produced damage to private homes, the road network, and agriculture. Damage was particularly severe in the municipalities of Orvieto and Porano (Fig. 1b). In these municipalities, slope failures were most abundant at Benano, Porano, and Sugano.

In this work, we investigate the rainfall induced landslides which occurred in the Orvieto area. The purpose of this study was to: (i) document the type, abundance and magnitude of the rainfall-induced landslides, and in particular the shallow slope failures which occurred in weathered volcanic rocks and soils present in the area, (ii) study the rainfall conditions that triggered the shallow landslides, including the timing of the slope failures, (iii) determine the geotechnical properties of the failed volcanic materials, and (iv) describe the type and extent of damage produced by the triggered slope failures. We further use the available event landslide information to test and update a geomorphological assessment of landslide hazards and risk for selected areas in Umbria, including the village of Sugano (Fig. 1b) (Reichenbach et al., 2005).

\section{Lithological and morphological setting}

The Orvieto area is characterized by a tabular volcanic mesa rimmed by a distinct escarpment, from a few to tens of meters in height. Buttes and isolated mesa remnants are locally present. Elevation in the area ranges from 110 to $636 \mathrm{~m}$. Slopes bounding the volcanic escarpment are very steep $\left(>65^{\circ}\right)$, locally vertical or overhanging. The remaining territory has slopes in the range from $0^{\circ}$ to $40^{\circ}$, with a modal value of $\sim 15^{\circ}$. Volcanic rocks cropping out in the area

Published by Copernicus GmbH on behalf of the European Geosciences Union. 

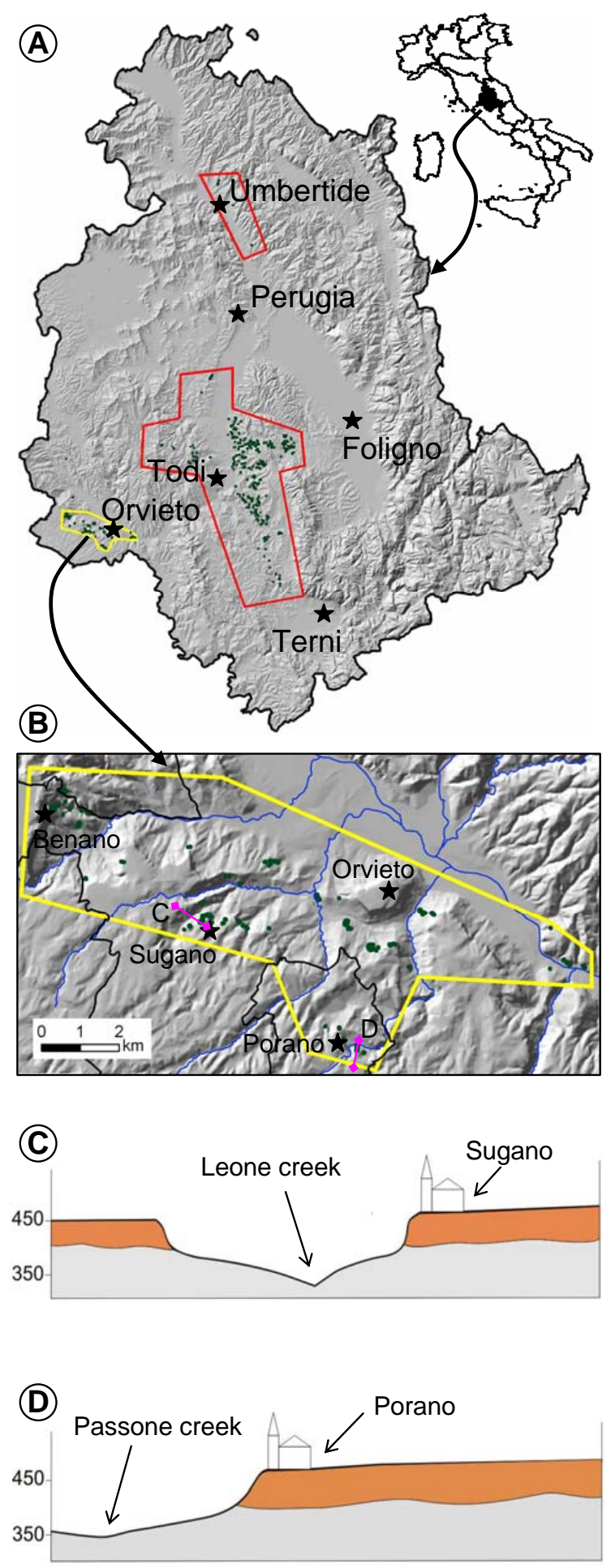

Fig. 1. Location and setting of the study area. (A) Shaded relief map of Umbria. Yellow and red lines show areas where field investigations to map landslides (shown as green dots) were conducted after the 4-6 December 2004 and the 25-27 December 2004 rainfall events. (B) Location of the Orvieto study area where landslides described in this paper (shown in green) were mapped through field work. Area of individual landslides exaggerated for illustration purposes. Violet lines show location of geological cross sections. (C) Simplified geological cross section at Sugano. Orange, volcanic deposits; grey, marine sediments. (D) Simplified geological cross section at Porano. Orange, volcanic deposits; grey, marine sediments. 
Table 1. Rain gauges used to study the rainfall conditions that resulted in landslides in the Orvieto area in December 2004. For the Allerona and the Orvieto Scalo rain gauges historical rainfall records were not available to compute the mean annual precipitation (MAP).

\begin{tabular}{llllll}
\hline Rain gauge & Latitude & Longitude & $\begin{array}{l}\text { Elevation } \\
(\mathrm{m})\end{array}$ & $\begin{array}{l}\text { MAP } \\
(\mathrm{mm})\end{array}$ & $\begin{array}{l}\text { Period } \\
(\text { years })\end{array}$ \\
\hline Orvieto & $42^{\circ} 43^{\prime} 08^{\prime \prime}$ & $12^{\circ} 43^{\prime} 08^{\prime \prime}$ & 315 & 816 & 69 \\
Orvieto Scalo & $42^{\circ} 43^{\prime} 57^{\prime \prime}$ & $12^{\circ} 07^{\prime} 49^{\prime \prime}$ & 117 & - & - \\
Allerona & $42^{\circ} 47^{\prime} 13^{\prime \prime}$ & $12^{\circ} 01^{\prime} 48^{\prime \prime}$ & 147 & - & - \\
Perugia & $43^{\circ} 09^{\prime} 36^{\prime \prime}$ & $12^{\circ} 26^{\prime} 44^{\prime \prime}$ & 493 & 850 & 79 \\
Foligno & $42^{\circ} 56^{\prime} 22^{\prime \prime}$ & $12^{\circ} 40^{\prime} 32^{\prime \prime}$ & 235 & 878 & 52 \\
Umbertide & $43^{\circ} 17^{\prime} 35^{\prime \prime}$ & $12^{\circ} 18^{\prime} 49^{\prime \prime}$ & 247 & 900 & 56 \\
Todi & $42^{\circ} 47^{\prime} 39^{\prime \prime}$ & $12^{\circ} 24^{\prime} 59^{\prime \prime}$ & 411 & 867 & 74 \\
Ripalvella & $42^{\circ} 50^{\prime} 40^{\prime \prime}$ & $12^{\circ} 18^{\prime} 01^{\prime \prime}$ & 453 & 953 & 5 \\
\hline
\end{tabular}

are part of the Monti-Vulsini volcanic complex, and contain lava flows, ignimbrites and pyroclastic deposits. These rocks overlie marine sediments Pliocene to Pleistocene in age, consisting manly of clay and silt, and subordinately of sand and gravel (Nappi et al., 1982, 1995; Buonasorte et al., 1988; Costantini et al., 1988; Faraone and Stoppa, 1988).

Landslides are abundant in the area. The geomorphological inventory map prepared for the Umbria Region by Antonini et al. (2002) shows a continuous belt of deep seated landslide deposits in the Orvieto area extending laterally for several kilometres. Landslides occur in the jointed volcanic cap and in the underlying marine clay. Stress analyses carried out on the Orvieto cliff have shown that failure of the volcanic cap has two main causes: (i) the increase of tensile stresses in the volcanic rock due to the different deformability of the pyroclastic rock in contrast to the more plastic underling marine sediments, and (ii) the reduction of the resisting stresses at the base of the cliff, due to landsliding in the underlying clay (Lembo-Fazio et al., 1984; Cecere and Lembo-Fazio, 1986; Barla et al., 1990; Diamanti and Soccodato, 1981). Guzzetti et al. (1996) determined that in the volcanic rocks slope movements are represented chiefly by: (i) falls, topples and slab failures of prismatic rock elements and related rock slides, (ii) differential (mostly vertical) lowering of the external-most portions of the volcanic cap, and (iii) relative movements of isolated blocks that locally form overhanging slopes. In the underlying stiff clay slides are rotational and translational. The latter failures are deep seated with a distinct retrogressive behaviour, and in some places turn into flow slides at the toe. Small shallow slides and flows develop in the colluvial cover of large landslide deposits or in the talus debris that locally covers the toe of the volcanic cap.

\section{Rainfall}

To investigate the rainfall conditions that resulted in landslides in the Orvieto area in December 2004, we used rainfall measurements obtained by eight rain gauges (Fig. 2 and Table 1). Of the eight rain gauges, the Orvieto, Orvieto Scalo and Allerona stations are located in south-western Umbria, at or near the area where landslides were most abundant. The Ripalvella, Todi and Perugia rain gauges are located in central Umbria, in or near areas where rainfall-induced slope failures were also numerous. The remaining two rain gauges are located in northern (Umbertide) and eastern (Foligno) Umbria (Fig. 2).

\subsection{Antecedent rainfall}

From 1 October to 3 December 2004, the Umbria Region experienced prolonged and intense rainfall with cumulative values over the 64-day period exceeding $300 \mathrm{~mm}$ (Figs. 2a, b). Locally, the cumulative rainfall for the selected period exceeded $49.5 \%$ of the mean annual precipitation (MAP) (Fig. 3). In the selected period, significant rainfall episodes occurred on 10-19 October, 26-31 October, 6-11 November, and 29-30 November (Fig. 2a). During these rainfall periods, total precipitation was most abundant in south-western Umbria (Fig. 2b). The first rainfall episode, from 10 to 19 October, was characterized by cumulative precipitation in excess of $150 \mathrm{~mm}$. Precipitation was particularly abundant at Orvieto $(189 \mathrm{~mm})$ and at Ripalvella $(165 \mathrm{~mm})$, and rainfall intensities peaked at Umbertide $(62.2 \mathrm{~mm}$ in $24 \mathrm{~h})$ and Orvieto $(56.6 \mathrm{~mm}$ in $24 \mathrm{~h})$. The second rainfall episode, from 26 to 31 October, was less severe, and was located in northern Umbria where cumulative precipitation was as much as $58.0 \mathrm{~mm}$ near Umbertide. In the period, rainfall was more intense at Umbertide, where $27.6 \mathrm{~mm}$ in $24 \mathrm{~h}$ were measured. The third rainfall episode, from 6 to 11 November, was characterized by total precipitation in the range from $34.4 \mathrm{~mm}$ (at Umbertide) to $90.6 \mathrm{~mm}$ (at Orvieto). The highest rainfall intensity was measured at Orvieto, where $28.0 \mathrm{~mm}$ in $24 \mathrm{~h}$ were 

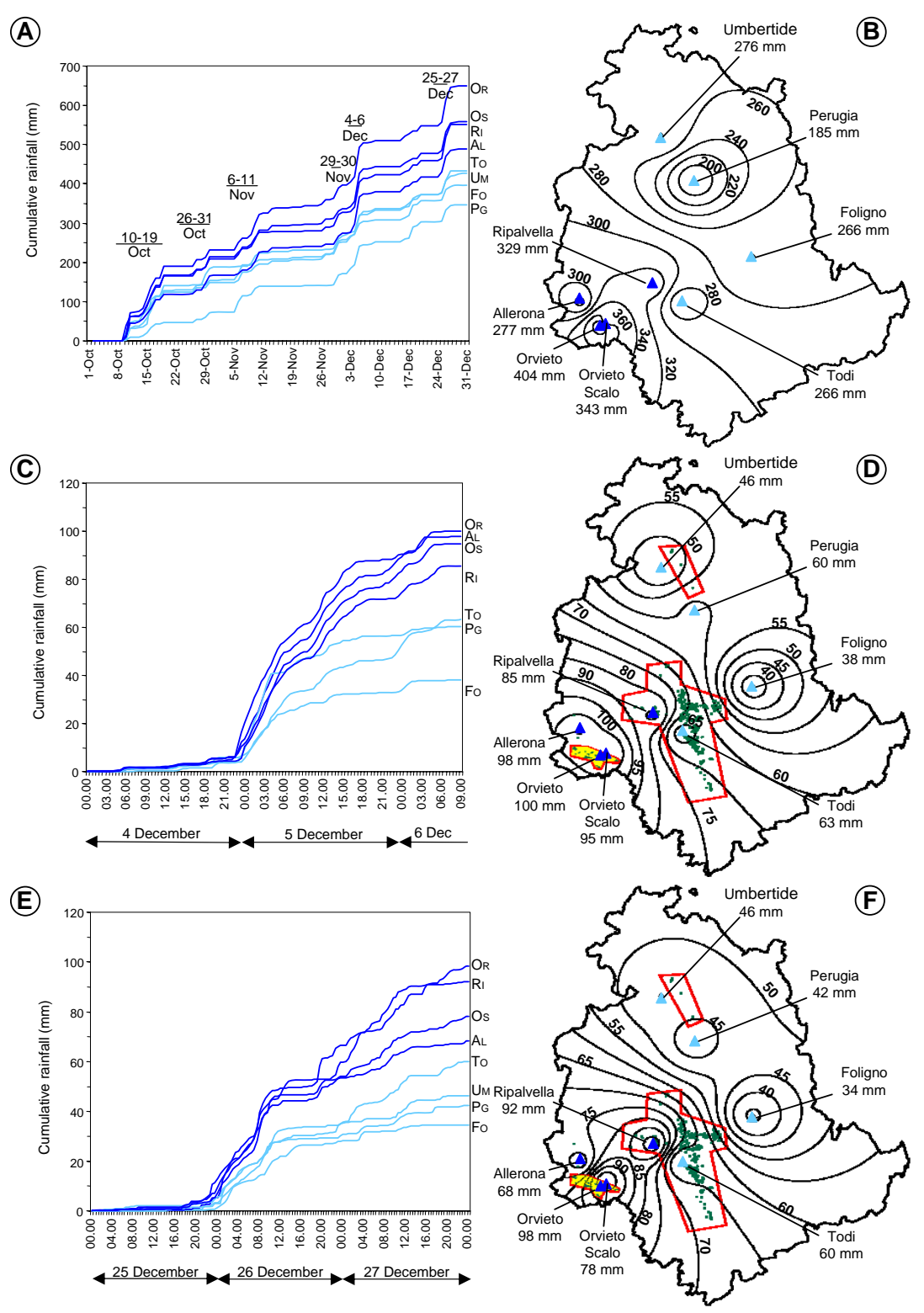

Fig. 2. Rainfall conditions that resulted in landslides in Umbria in December 2004. (A) Rainfall history for the period from 1 October to 31 December 2004 (antecedent conditions). (B) Map showing cumulative rainfall in the period from 1 October to 3 December 2004. (C) Rainfall history for the period between 4 December, at 00:00, and 6 December 2004, at 09:00. (D) Map showing cumulative rainfall for the 4-6 December 2004 rainfall event. (E) Rainfall history for the period between 25 December, at 00:00, and 27 December, at 24:00. (F) Map showing cumulative rainfall for the 25-27 December 2004 rainfall event. Rain gauges arranged geographically in two groups. Group 1, dark blue triangles in the maps and dark blue lines in the graphs: Or, Orvieto; Os, Orvieto Scalo; Al, Allerona; Ri, Ripalvella. Group 2, light blue triangles in the maps and light blue lines in the graphs: To, Todi; Fo, Foligno; Pg, Perugia; Um, Umbertide. In the maps, thick lines show the Umbria regional boundary, thin lines are contours of rainfall, red lines outline areas where landslides were mapped through field investigations. Yellow polygon shows the Orvieto study area (Fig. 6). Area of the individual landslides exaggerated for illustration purposes.

recorded on 10 November. The last rainfall episode, from 29 to 30 November, was characterized by cumulative rainfall in the range from $20.2 \mathrm{~mm}$ (at Orvieto Scalo) to $33.0 \mathrm{~mm}$ (at Todi). This short rainfall episode was less severe that the previous episodes, and occurred four days before the 4-6 December 2004 rainfall event that resulted in abundant landslides.

\subsection{The 4-6 December 2004 event}

At the end of a particularly wet season, and following the 2930 November rainfall episode, a particularly intense rainfall event hit the south-western part of the Umbria Region from 4 to 6 December 2004 (Figs. 2c, d). The event started in the early hours of 4 December with a light rain. Less than $6 \mathrm{~mm}$ 
were measured between 05:00 and 22:00. Rainfall intensity increased rapidly between 22:00 and 22:30. The first rainfall burst lasted $6.5 \mathrm{~h}$, from 22:30 of 4 December to 05:00 of 5 December. During this period, the Allerona rain gauge measured $5.4 \mathrm{~mm}$ in $30 \mathrm{~min}$, and $10.2 \mathrm{~mm}$ in $1 \mathrm{~h}$, with a cumulative rainfall for $6.5 \mathrm{~h}$ exceeding $45 \mathrm{~mm}$. The rainfall event continued with a reduced intensity until 10:00, when a second rainfall burst started with an intensity of about $3 \mathrm{~mm} / \mathrm{h}$ and lasted until about 17:00 (maximum intensity was measured at Allerona with $6.6 \mathrm{~mm} / \mathrm{h})$. The event ended at approximately 05:00 on 6 December with two consecutive rainfall bursts exhibiting rainfall intensities of 2.3 and $2.2 \mathrm{~mm} / \mathrm{h}$, respectively. At the Orvieto rain gauge, precipitation totalled $100 \mathrm{~mm}$ in $48 \mathrm{~h}$, corresponding to an average intensity in excess of $2 \mathrm{~mm} / \mathrm{h}$. Comparable values were observed at Orvieto Scalo $(94.8 \mathrm{~mm})$ and at Allerona $(97.8 \mathrm{~mm})$. The other rain gauges exhibited a similar temporal trend of the rainfall, with little or no difference in the time and the duration of the individual rainfall bursts (Fig. 2c). Figure $2 d$ reveals a distinct geographical pattern for the rainfall. The cumulative rainfall for the 30 -h period was highest between Orvieto and Allerona, and decreased rapidly to the $\mathrm{N}$ (45.8 $\mathrm{mm}$ at Umbertide) and to the $\mathrm{E}$ ( $38.1 \mathrm{~mm}$ at Foligno).

\subsection{The 25-27 December 2004 event}

The last rainfall event in the studied period hit the Umbria Region from 25 to 27 December 2004 (Figs. 2e, f). In the south-western part of Umbria, the rainfall event started in the early morning of 25 December with a light rain. Less than $4 \mathrm{~mm}$ of rain were measured in the 14-h period between 06:00 and 20:00 on 25 December. Rainfall intensity increased between 20:00 and 22:00, and increased markedly after 22:00. The intense rainfall lasted $12.5 \mathrm{~h}$, until 10:30 on 26 December, with an average intensity of $3.5 \mathrm{~mm} / \mathrm{h}$ (at Orvieto). The intense rainfall period was characterized by individual bursts, which lasted from less than one hour to few hours. Inspection of Fig. 2e indicates differences in the time and the duration of the individual rainfall bursts. During this intense rainfall period, the Orvieto rain gauge measured $6.8 \mathrm{~mm}$ in $30 \mathrm{~min}, 10.6 \mathrm{~mm}$ in $1 \mathrm{~h}$ and $15.8 \mathrm{~mm}$ in $2 \mathrm{~h}$, with a cumulative rainfall for $12.5 \mathrm{~h}$ exceeding $43 \mathrm{~mm}$. The event continued with a reduced rainfall intensity (about $1.6 \mathrm{~mm} / \mathrm{h}$ at Orvieto and $0.7 \mathrm{~mm} / \mathrm{h}$ at Allerona), and ended between 09:00 and 15:00 on 27 December. In the latter period, individual rainfall bursts were observed, e.g., at the Orvieto rain gauge between 19:00 and 20:00 on 26 December. The event was more severe and lasted longer in south-western Umbria, between Orvieto and Ripalvella, and was shorter and less intense in the northern (Umbertide) and eastern (Foligno) Umbria (Fig. 2e). Figure $2 \mathrm{f}$ shows that the geographical pattern of the event precipitation was similar to the pattern observed for the 4-6 December event. The cumulative rainfall for the 66-h period between 06:00 on 25 December and 24:00 on 27 December exhibits maximum values between
Orvieto (98.4 mm) and Ripalvella $(92.0 \mathrm{~mm})$, and decreases rapidly to the $\mathrm{N}$ (42.4 $\mathrm{mm}$ at Perugia) and to the $\mathrm{E}(34.4 \mathrm{~mm}$ at Foligno).

\subsection{Historical rainfall data}

Figure 3 shows the distribution of the MAP for 39 rain gauges in Umbria and in the surrounding areas, for the 79year period between 1921 and 1999. During this period, in the central part of the region where open valleys and hills are present, MAP was less than about $950 \mathrm{~mm}$, with a minimum value of $754 \mathrm{~mm}$ at Castiglione del Lago. In the same period, along the Apennines Mountain range MAP exceeded $1300 \mathrm{~mm}$, with a maximum value of $1390 \mathrm{~mm}$ at Scirca. In the southern and the south-western parts of the region, where morphology is tabular or hilly, MAP ranged between 826 (Orvieto) and $1156 \mathrm{~mm}$ (Soriano del Ciminno and Proceno) ${ }^{1}$.

Figure 4 shows the cumulative rainfall measured at the Orvieto rain gauge in October, November, and December, 2004. In the considered period, the monthly rainfall was from $53 \%$ (November) to $186 \%$ (December) higher than the average monthly values in the period form 1921 to 1999 (red dashed lines in Fig. 4). Analysis of the available historical record indicates that monthly rainfall at the Orvieto rain gauge exceeded $200 \mathrm{~mm}$ nine times in October, four times in November, and four times in December, with a maximum monthly value of $313.5 \mathrm{~mm}$ in October 1964. Based on the available historical record, the return period of the observed monthly rainfall for December 2004 was less than 17 years. However, analysis of the cumulative rainfall for the 3month period from October to December (Fig. 5a) indicates that only once (in 1964, $644 \mathrm{~mm}$ ) the cumulative rainfall for the 3-month period from October to December exceeded the cumulative value measured in 2004 (592 $\mathrm{mm})$, and only twice (in 1960, $744 \mathrm{~mm}$, and in 1928, $734 \mathrm{~mm}$ ) the cumulative precipitation for the 4-month period from September to December (Fig. 5b) exceeded the rainfall measured in 2004 $(710 \mathrm{~mm})$. This information indicates that the return period for the 2004 rainfall sequence was between 26 and 40 years. Analysis of the historical daily-rainfall record further indicates that high intensity rainfall is not uncommon in the Orvieto area. At the Orvieto rain gauge, in the 79-year period from 1921 to 1999 , daily rainfall exceeded six times $100 \mathrm{~mm}$, and 23 times $60 \mathrm{~mm}$. At the same rain gauge, nine events exceeding $100 \mathrm{~mm}$, and three events exceeding $150 \mathrm{~mm}$ in 2 days were recorded. Particularly severe 2-day events occurred on 21-22 October 1946 (141.0 mm), and on 21-22 October 1993 (137.8 mm).

\footnotetext{
1 Source of rainfall data: Servizio Idrografico Nazionale and Regionale dell'Umbria.
} 


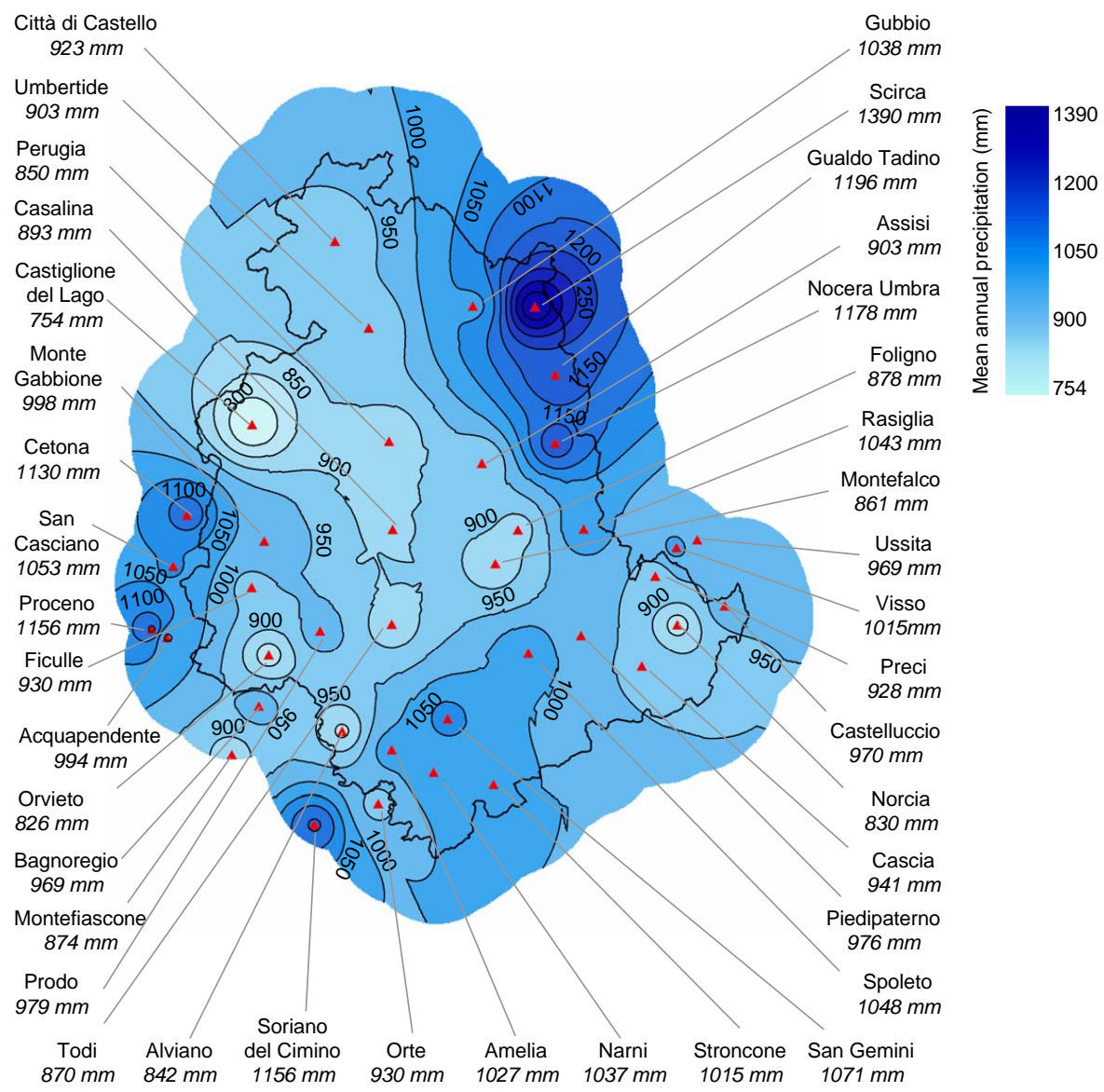

Fig. 3. Umbria Region. Map showing mean annual precipitation (MAP) for 39 rain gauges (red triangles) in the 78 -year period between 1921 and 1999.

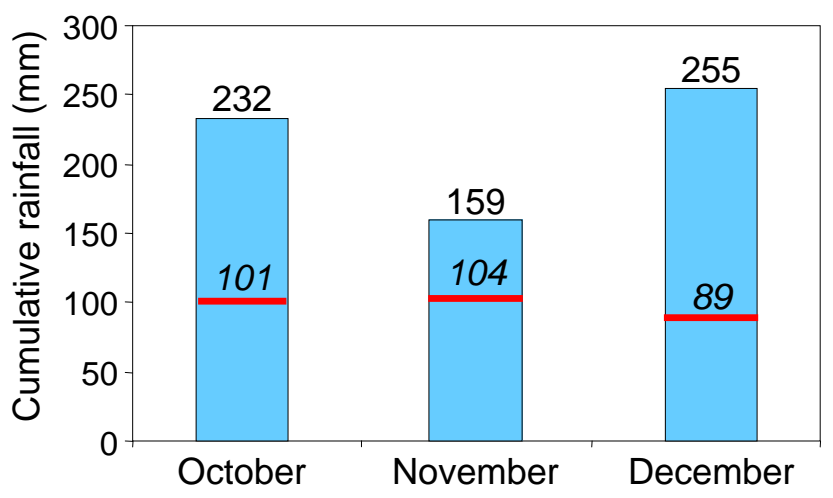

Fig. 4. Bars show cumulative rainfall at the Orvieto rain gauge for October (31 days), November (30 days), and December (27 days) 2004. Red lines and italic numbers show long-term (1921-1999) monthly averages.

\section{Landslide inventory}

Following the December 2004 rainfall events we performed field surveys to identify and map the rainfall induced landslides. Landslides were mapped in the field at 1:10000 scale using topographic base maps published in 1993 and orthorectified aerial photographs taken in 1999. To map the rainfall induced landslides in the Orvieto area, six geomorphologists in two teams searched an area of about $42 \mathrm{~km}^{2}$ (yellow line in Fig. 6a) in 5 days. To map the landslides, we drove systematically along the main, the secondary, and the farm roads present in the study area. We stopped where single or multiple landslides were identified, and at scenery points to check individual and multiple slopes. Care was taken in mapping slope failures in urban and sub-urban areas. In the field, we took single and pseudo-stereoscopic photographs of each landslide or group of landslides. We used the photographs to precisely locate the landslides on topographic maps, to help characterize the type and the size of the mass movements, to determine the local terrain gradient, and to estimate the thickness of the material involved in the failure and the size of individual fallen blocks. We searched information on the 
time of failure and the speed and the type of movements by interviewing local people. Due to the presence of a dense forest, mapping of the landslide features was problematic along the sub-vertical escarpment that rims the volcanic deposits between the villages of Benano and Porano (Figs. 1 and 6). In this area, uncertainty in the location of the landslides is due to the small size of the slope failures, the thick forest cover, and to the poor quality of the available topographic maps along the sub-vertical escarpment (Fig. 6b).

The obtained event landslide inventory map for the Orvieto area (Fig. 6a) shows 105 landslides, for a total landslide area of $1.01 \times 10^{5} \mathrm{~m}^{2}, 0.02 \%$ of the study area. The estimated total landslide volume exceeds $1.38 \times 10^{5} \mathrm{~m}^{3}$. These figures represent $10.8 \%$ of the total mapped landslide area, and $8.1 \%$ of the total mapped landslide volume produced by the rainfall events in December 2004 in Umbria. In the Orvieto area, the average landslide density was 2.5 slope failures per square kilometre, and locally exceeded 8 landslides per square kilometre (e.g. in the vicinity of the Sugano and the Benano villages, see Figs. 6b, c).

In the Orvieto area, the rainfall induced landslides were chiefly shallow and subordinately deep seated failures (Table 2) that affected marine deposits and weathered volcanic rocks, soils and debris. Shallow failures encompassed soil slides, debris flows, debris avalanches, mud flows, and debris and rock falls. Deep seated failures were translational and complex landslides. Shallow and deep seated landslides affecting the marine sediments were typical for the area, whereas shallow landslides affecting the volcanic deposits were less well known and poorly documented in Umbria (Guzzetti et al., 1996).

\subsection{Landslides in weathered volcanic deposits}

Landslides that originated from weathered volcanic deposits were mostly composite movements (WP/WLI, 1990; Cruden and Varnes, 1996) encompassing shallow slides and falls that turned abruptly into rapid moving flows and avalanches. The landslide material travelled along the sub-vertical volcanic escarpment, and was deposited at the base of the cliff where the terrain gradient is low, horizontal in places. Adopting the classification of mass movements proposed by Cruden and Varnes (1996), we classify the shallow landslides in the volcanic deposits into three, partially overlapping groups (Fig. 7). The first group (Group A) consists of composite failures including soil slides, debris flows, and debris and rock falls. The second group (Group B) consists of soil slides that rapidly evolved into debris avalanches or debris flows. The third group (Group C) encompasses rock falls and topples. Distinction between the three landslide groups is fuzzy, and attribution of individual landslides to one of the three groups was a matter of interpretation.

Group A (soil slide - debris flow - debris and rock fall, Fig. 7a), with 29 mapped slope failures $(27.6 \%)$ was the most numerous group of landslides in weathered volcanic materi-
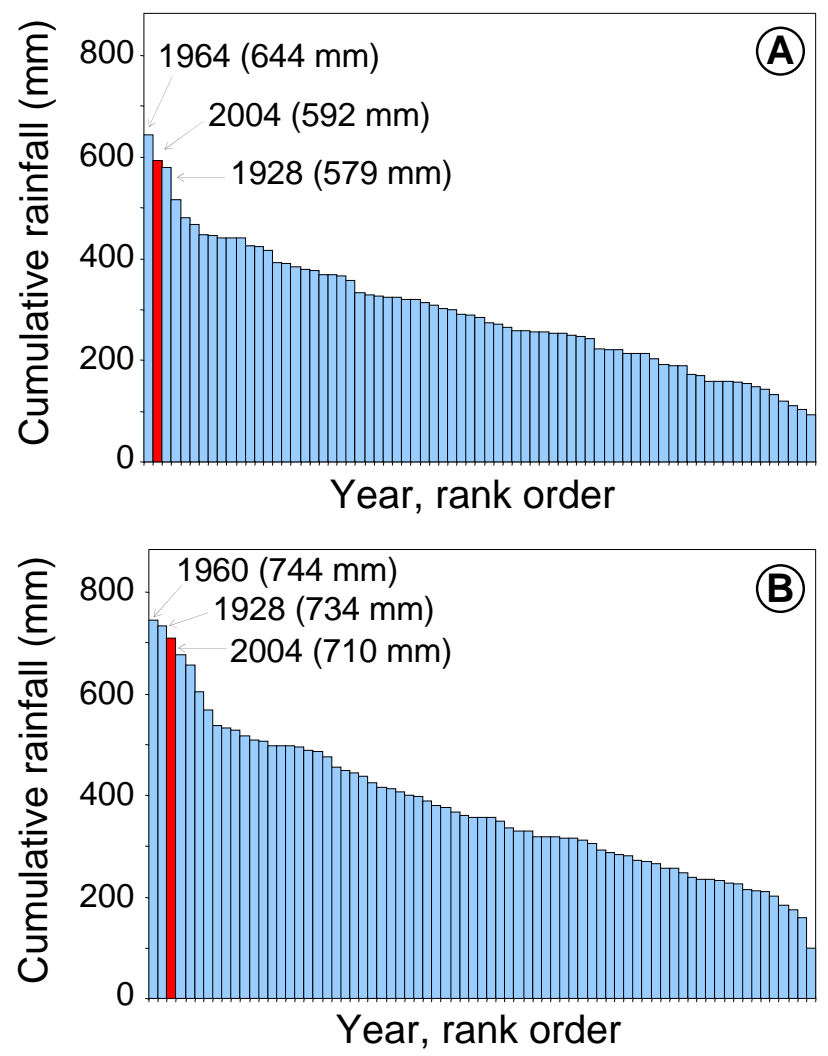

Fig. 5. Blue bars show cumulative rainfall for the Orvieto rain gauge, for the 3-month period from October to December (A), and for the 4-month period from September to December $(\mathbf{B})$, in the period between 1921 and 1999. Bars arranged from high (left) to low (right) values of cumulative yearly rainfall. Red bars show cumulative rainfall for the same 3-month and 4-month periods in 2004.

als. Slope failures in this group covered the largest landslide area $\left(1.46 \times 10^{4} \mathrm{~m}^{2}, 14.4 \%\right)$, and an estimated total volume of $2580 \mathrm{~m}^{3}(1.9 \%)$ (Table 2). The smallest landslide in this group has an area of $38 \mathrm{~m}^{2}$, the largest mapped failure covers $3134 \mathrm{~m}^{2}$, and the average landslide area is $503 \mathrm{~m}^{2}$ (st. dev. = $586 \mathrm{~m}^{2}$ ). Inspection of Figs. $6 \mathrm{a}$ and $\mathrm{b}$ shows that landslides were most abundant near Sugano. In this area, field surveys revealed that a 2 to $10 \mathrm{~m}$ thick layer of basalt formed a subvertical, rocky cliff within the larger volcanic escarpment, and that most of the landslides originated from the upper part of the escarpment, above the rock cliff. Landslides initiated chiefly as shallow, translational slides (soil slide) on slopes ranging from $30^{\circ}$ to $70^{\circ}$ (average $60^{\circ}$ ), and involved soil, weathered volcanic rock, and man made debris (Figs. 8a, c). In the source area, thickness of the failed material ranged between $30 \mathrm{~cm}$ and $2 \mathrm{~m}$ (estimated average $60 \mathrm{~cm}$ ), for a source volume in the range from $10 \mathrm{~m}^{3}$ to $700 \mathrm{~m}^{3}$ (estimated average $90 \mathrm{~m}^{3}$ ). Most of the soil slides mobilized completely, leaving empty scars from which the soil or the debris slid or flowed (Fig. 8a, c). Along the transport area, the failed material mostly flowed along the steep slope until it reached the 
Table 2. Characteristics of 105 landslides triggered by high-intensity rainfall events on 4-6 December and on 25-27 December, 2004, in the Orvieto area. Landslides inventoried through fieldwork.

\begin{tabular}{|c|c|c|c|c|c|c|c|c|c|c|c|c|}
\hline \multicolumn{5}{|c|}{ Landslides } & \multicolumn{4}{|c|}{ Landslide area } & \multicolumn{4}{|c|}{ Landslide volume } \\
\hline & type of movement & material & number & $\begin{array}{l}\text { percent } \\
\%\end{array}$ & $\begin{array}{l}\text { total } \\
\mathrm{m}^{2}\end{array}$ & $\begin{array}{l}\min \\
\mathrm{m}^{2}\end{array}$ & $\begin{array}{l}\max \\
\mathrm{m}^{2}\end{array}$ & $\begin{array}{l}\text { mean } \\
\mathrm{m}^{2}\end{array}$ & $\begin{array}{l}\text { total } \\
\mathrm{m}^{3}\end{array}$ & $\begin{array}{l}\min \\
\mathrm{m}^{3}\end{array}$ & $\begin{array}{l}\max \\
\mathrm{m}^{3}\end{array}$ & $\begin{array}{l}\text { mean } \\
\mathrm{m}^{3}\end{array}$ \\
\hline shallow & $\begin{array}{l}\text { soil slide - debris flow - } \\
\text { debris and rock fall }\end{array}$ & volcanic & 29 & 27.6 & 14600 & 38 & 3134 & 503 & 2580 & 10 & 1000 & 89 \\
\hline shallow & soil slide - debris avalanche & volcanic & 4 & 3.8 & 9445 & 642 & 6556 & 2361 & 2000 & 200 & 1200 & 500 \\
\hline shallow & rock fall and topple & volcanic & 3 & 2.9 & 1500 & 176 & 738 & 505 & 155 & 25 & 80 & 51 \\
\hline shallow & soil slide & marine sediments & 38 & 36.2 & 19300 & 35 & 1745 & 509 & 2280 & 7 & 250 & 60 \\
\hline shallow & debris flow & marine sediments & 17 & 16.2 & 12700 & 101 & 2737 & 750 & 2050 & 20 & 600 & 120 \\
\hline shallow & mud flow & marine sediments & 8 & 7.6 & 3600 & 219 & 1394 & 453 & 560 & 35 & 220 & 70 \\
\hline deep seated & translational slide & marine sediments & 6 & 5.7 & 40100 & 813 & 18612 & 6683 & 128500 & 500 & 100000 & 21416 \\
\hline Total & all types & & 105 & & 101245 & 35 & 18612 & 966 & 138130 & 7 & 100000 & 1315 \\
\hline
\end{tabular}

Table 3. Location and time or period of occurrence of landslides and inundation produced by the 4-6 December 2004, and the 25-27 December 2004, rainfall events in the Orvieto area. ID refers to landslide localities shown in Fig. 6.

\begin{tabular}{lllll}
\hline ID & date & time or period & type of event & area \\
\hline 1 & 5 December & Beginning in the early morning & Landslides and debris flows & Corbara road \\
2 & & Beginning in the early morning & Shallow landslides & Torre San Severo \\
3 & & Beginning in the early morning & Shallow landslides & Benano to Orvieto road \\
4 & & Beginning in the late morning & Inundation along the Paglia River & Ponte Giulio \\
5 & & Beginning in the late morning & Inundation along the Paglia River & Orvieto Scalo \\
6 & 6 December & During the day & Deep seated landslide & Badia and Podere Cipresso \\
7 & & During the day & Soil slide - debris avalanche & Sugano to Scalette road \\
8 & 27 December & $11: 15$ & Soil slide - debris avalanche & Sugano \\
\hline
\end{tabular}

sub-vertical cliff (debris flow). At the cliff edge the type of movement changed, and the landslide material travelled by a combination of falling, flowing and sliding. Along the rock cliff, the slope failures caused little erosion of the soil, the debris and the rock fragments present on the steep slope, i.e., landslide entrenchment was minimum. Where the volcanic cliff was vertical or overhanging, erosion did not occur, and only vegetation was locally disrupted (Fig. 8c). The landslide material deposited at the base of the escarpment, forming rock and debris cones that locally incorporated disrupted vegetation. In places, individual boulders of volcanic rock, up to $0.5 \mathrm{~m}^{3}$ in volume, travelled a short distance beyond the toe of the deposit (Fig. 6b).

Group B (soil slide - debris avalanche, Fig. 7b) contains four slope failures (3.8\%), for a total landslide area of $9445 \mathrm{~m}^{2}$, and an estimated total landslide volume of $2000 \mathrm{~m}^{3}$ (Table 2). Area of individual landslides ranges from $642 \mathrm{~m}^{2}$ to $6556 \mathrm{~m}^{2}$ (average $=2361 \mathrm{~m}^{2}$, st. dev. $=2429 \mathrm{~m}^{2}$ ), with an estimated volume in the range between $200 \mathrm{~m}^{2}$ and $1200 \mathrm{~m}^{3}$ (average $\left.=500 \mathrm{~m}^{3}\right)$. Two of these composite failures occurred at and near Porano (Fig. 6a), and the other two occurred near Sugano (Fig. 6b). The mass movements origi- nated as shallow translational slides from slopes in the range between $40^{\circ}$ and $70^{\circ}$ (average $50^{\circ}$ ). After failure, the slides rapidly mobilized into debris avalanches. Inspection of the source areas allowed estimating the original landslide volume of the soil slides in the range between $150 \mathrm{~m}^{3}$ to $800 \mathrm{~m}^{3}$. In the transport area, the material accelerated possibly to avalanche speed, and locally incorporated soil, debris, fractured and weathered bedrock, and vegetation, largely increasing the individual landslide volume (Table 2). The landslide material was deposited at the base of the steep volcanic escarpment. Geometry of the deposit varied depending on the mobility of the landslide material at the base of the escarpment, and on local morphology. As an example, the debris avalanche at Porano (Figs. 6c, 7b, 8e) travelled for more than $70 \mathrm{~m}$ on a slope having a gradient of $10^{\circ}$ or less.

Group C lists three rock falls and topples (2.9\%), for a total landslide area of $1500 \mathrm{~m}^{2}(1.5 \%)$, and an estimated total landslide volume of $155 \mathrm{~m}^{3}$ (Fig. 7c and Table 2). Area of individual landslides ranges from $176 \mathrm{~m}^{2}$ to $738 \mathrm{~m}^{2}$, with an average value of $505 \mathrm{~m}^{2}$ (st. dev. $=239 \mathrm{~m}^{2}$ ). These landslides initiated from very steep $\left(>70^{\circ}\right)$, locally vertical or overhanging slopes, as single or multiple rock falls (Fig. 7c). 


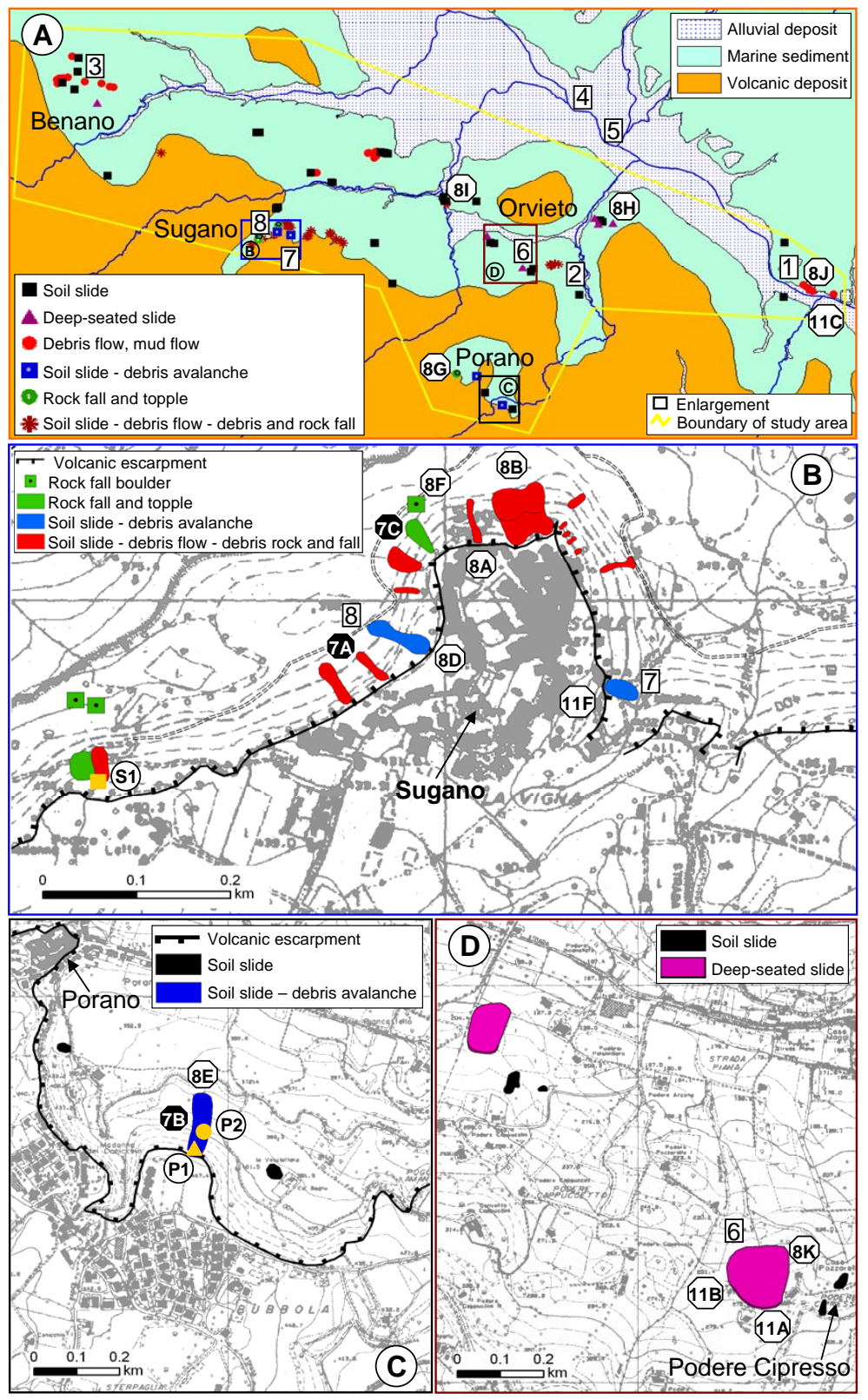

Fig. 6. Event landslide inventory map for the Orvieto area. (A) Simplified geological map, and distribution of 105 rainfall induced landslides. (B) Portion of landslide event inventory map for the Sugano village. (C) Portion of landslide event inventory map for the Porano area. (D) Portion of landslide event inventory map for the Badia and Podere Cipresso area. Numbers in circles show location of samples for geotechnical analyses (Fig. 10). Numbers in squares show location of landslides for which the time or period of occurrence is known (Table 3 and Fig. 9). Numbers in hexagons indicate location of landslides shown in Figs. 7, 8 and 11.

Locally, natural soil and debris resulting from human activities was incorporated in the slope movements. Initial movement was characterized by toppling (Fig. 8g) or minor sliding. Following detachment, the landslide material proceeded rapidly down slope by flying, bouncing and subordinately sliding, and was deposited at the base of the escarpment forming distinct rock and debris cones, which locally contained disrupted trees and chaparrals. Individual rock fall boulders, $0.5 \mathrm{~m}^{3}$ to $8 \mathrm{~m}^{3}$ in volume (Fig. $8 \mathrm{f}$ ), travelled well beyond the toe of the main rock fall deposit, and up to a distance of $100 \mathrm{~m}$ from the base of the cliff.

\subsection{Landslides in marine sediments}

Landslides in marine sediments, including clay, silt, sand and gravel, were mostly slow moving, shallow and subordinately deep seated slides (Fig. 6d). A few debris flows and mud 


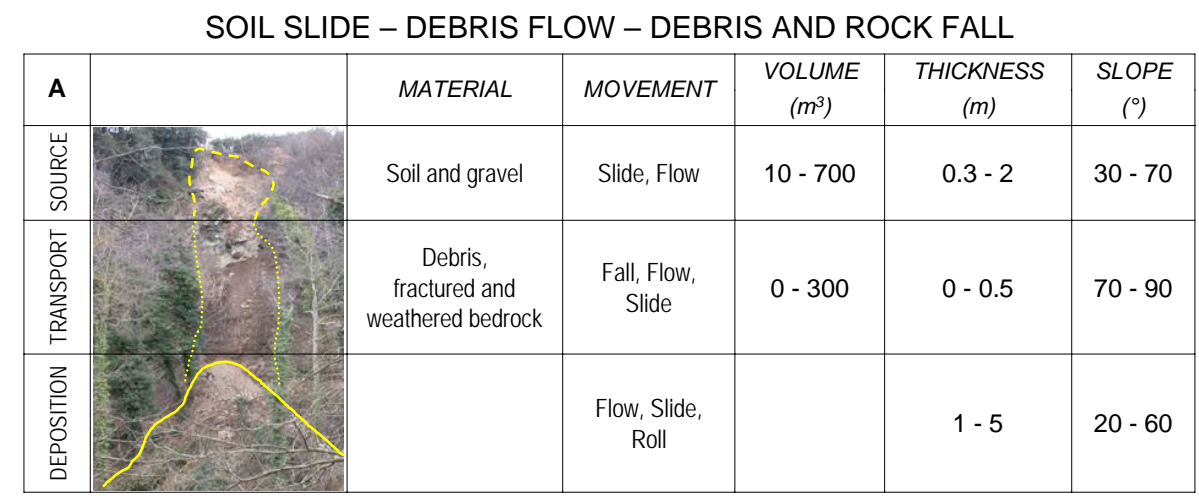

\begin{tabular}{|c|c|c|c|c|c|c|}
\hline \multicolumn{7}{|c|}{ SOIL SLIDE - DEBRIS AVALANCHE } \\
\hline B & & MATERIAL & MOVEMENT & $\begin{array}{c}\text { VOLUME } \\
\left(\mathrm{m}^{3}\right)\end{array}$ & $\begin{array}{c}\text { THICKNESS } \\
\text { (m) }\end{array}$ & $\begin{array}{c}\text { SLOPE } \\
\left({ }^{\circ}\right)\end{array}$ \\
\hline 岁 & Sesti ins & Soil and gravel & Slide & $150-800$ & $1-2$ & $40-70$ \\
\hline 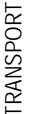 & & $\begin{array}{c}\text { Debris, } \\
\text { fractured and } \\
\text { weathered bedrock }\end{array}$ & Flow & $50-400$ & $0.2-0.5$ & 70 \\
\hline 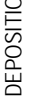 & & & Flow, Slide & & $1-5$ & $5-20$ \\
\hline
\end{tabular}

ROCK FALL AND TOPPLE

\begin{tabular}{|c|c|c|c|c|c|c|}
\hline C & & MATERIAL & MOVEMENT & $\begin{array}{c}\text { VOLUME } \\
\left(\mathrm{m}^{3}\right)\end{array}$ & $\begin{array}{c}\text { THICKNESS } \\
\text { (m) }\end{array}$ & $\begin{array}{c}\text { SLOPE } \\
\left({ }^{\circ}\right)\end{array}$ \\
\hline $\begin{array}{l}\text { U } \\
\text { 号 } \\
\text { ○ }\end{array}$ & $\frac{1}{408}$ & $\begin{array}{c}\text { Debris, } \\
\text { fractured and } \\
\text { weathered bedrock }\end{array}$ & $\begin{array}{l}\text { Fall or } \\
\text { Toppling }\end{array}$ & $5-100$ & $0.5-2$ & $70-90$ \\
\hline 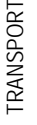 & 8 & & $\begin{array}{l}\text { Fly, Roll, } \\
\text { Bounce }\end{array}$ & & $0-0.5$ & $50-90$ \\
\hline $\begin{array}{l}\text { 을 } \\
\text { E } \\
\text { 을 } \\
\text { 㟧 }\end{array}$ & 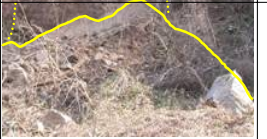 & & $\begin{array}{l}\text { Roll, Bounce, } \\
\text { Slide }\end{array}$ & & $1-5$ & $10-50$ \\
\hline
\end{tabular}

Fig. 7. Rainfall-induced landslides in volcanic rocks, soils and man made debris in the Orvieto area. Landslides classified in three groups, based on type of movement. For each group, main features in the source (dashed yellow line), travel (dotted yellow line), and deposition (continuous yellow line) areas are shown. (A) Group A, soil slide - debris flow - debris and rock fall. Photograph shows landslide at Sugano (Fig. 6b). (B) Group B, soil slide - debris avalanche. Photograph shows landslide near Porano (Fig. 6c). (C) Group C, rock fall and topple. Photograph shows landslide at Sugano (Fig. 6b).

flows were mapped in terraced slopes and in badlands, respectively.

Soil slides were the most abundant type of failure in marine sediments ( 38 in number, $36.2 \%$ ), and covered $1.93 \times 10^{4}$ $\mathrm{m}^{2}, 19.0 \%$ of the total mapped landslide area (Table 2). The shallow failures were rectangular or circular in shape, from $4 \mathrm{~m}$ to $62 \mathrm{~m}$ long (average $=28 \mathrm{~m}$ ), and with an area ranging from $35 \mathrm{~m}^{2}$ to $1745 \mathrm{~m}^{2}$ (average $=509 \mathrm{~m}^{2}$ ). The slides occurred on slopes not exceeding $20^{\circ}$, and involved chiefly the weathered soil, with an estimated depth in the range from $20 \mathrm{~cm}$ to $1 \mathrm{~m}$. Based on the geometry and the morphology of the soil slides, we estimate that the shear surface in the detachment area was mostly planar and parallel to the topographic surface. Soil slides were most abundant in cultivated areas, and in the deposit of large, pre-existing landslides.

A total of 17 debris flows (16.2\%) and 8 mud flows (7.6\%) were mapped where marine deposits crop out. These shallow landslides were long and narrow failures, ranging from $20 \mathrm{~m}$ to $100 \mathrm{~m}$ in length (average $=35 \mathrm{~m}$ ), and from $5 \mathrm{~m}$ to $35 \mathrm{~m}$ in width (average $=15 \mathrm{~m}$ ). Landslide area ranged from $101 \mathrm{~m}^{2}$ to $2737 \mathrm{~m}^{2}$ (average $=750 \mathrm{~m}^{2}$ ), with estimated landslide volumes in the range from $20 \mathrm{~m}^{3}$ to $600 \mathrm{~m}^{3}$ (Table 2). Debris 

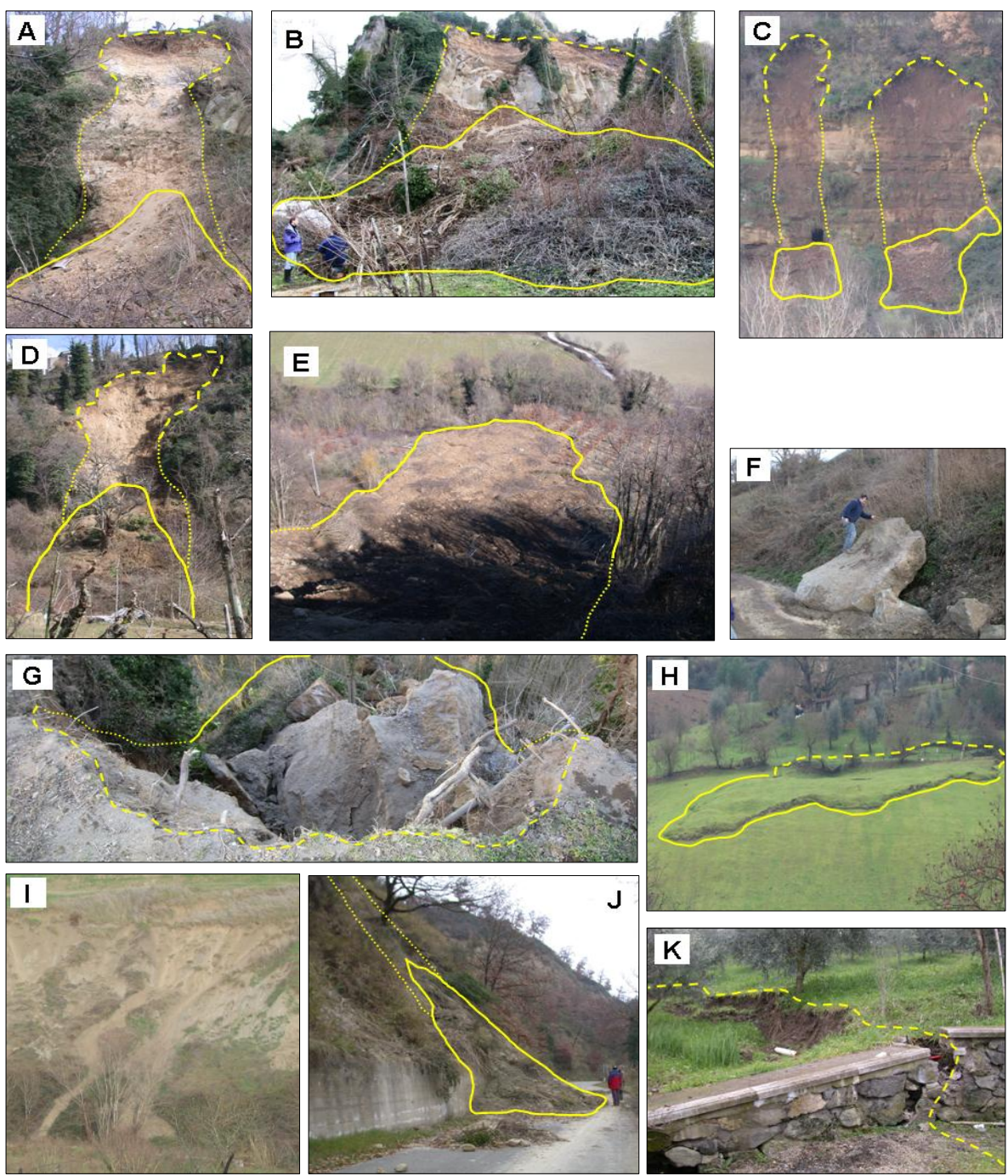

Fig. 8. Landslides triggered by intense rainfall in December 2004 in the Orvieto area. Dashed yellow line shows source area, dotted yellow line shows travel area, continuous yellow line shows deposition area. (A), (B) and (C) landslides near Sugano, pertaining to Group A (soil slide - debris flow - debris and rock fall). (D) Soil slide - debris avalanche near Sugano occurred at 11:15 on 27 December (8 in Table 3 and Fig. 6b). (E) Deposition area of a soil slide - debris avalanche near Porano. (F) Rock fall boulder near Sugano that travelled beyond the toe of the main rock fall deposit. (G) Toppling of pyroclastic blocks at Castel Rubello. (H) Soil slide on marine sediments S of Orvieto. (I) Mud flows in active badlands area in marine sediments. (J) Debris flow from a terraced slope and road cut where gravel and sand crop out. (K) Detail of the escarpment of the Badia and Podere Cipresso deep seated slide (6 in Table 3 and Fig. 6d).

and mud flows both originated from locally very steep slopes $\left(>60^{\circ}\right)$. Mud flows were mapped in actively eroding areas and in minor badlands (Fig. 8i), where fine sediments (i.e., clay and silt) prevail. Debris flows developed from terraced slopes and road cuts (Fig. 8j), where coarse sediments (i.e., gravel and sand) crop out.

Six (5.7\%) deep seated, mostly translational landslides involving clay and silt, and subordinately sand, were mapped where marine sediments crop out. The six landslides covered a total of $4.01 \times 10^{4} \mathrm{~m}^{2}$, corresponding to $39.6 \%$ of the total mapped landslide area (Table 2), and ranged in size from a few tens to few hundreds of meters in length, and from
$813 \mathrm{~m}^{2}$ to $1.86 \times 10^{4} \mathrm{~m}^{2}$ in area (Table 2). For one slope failure (Badia and Podere Cipresso, see Figs. 8k, 11a, b) landslide volume was estimated exceeding $1.00 \times 10^{6} \mathrm{~m}^{3}$.

\section{Landslide timing}

Following the December 2004 landslide-triggering rainfall events, we attempted to collect information on the time of the triggered slope failures. Despite our efforts, by interviewing local residents we obtained reasonably accurate information on the time of failure for only one debris avalanche at Sugano 

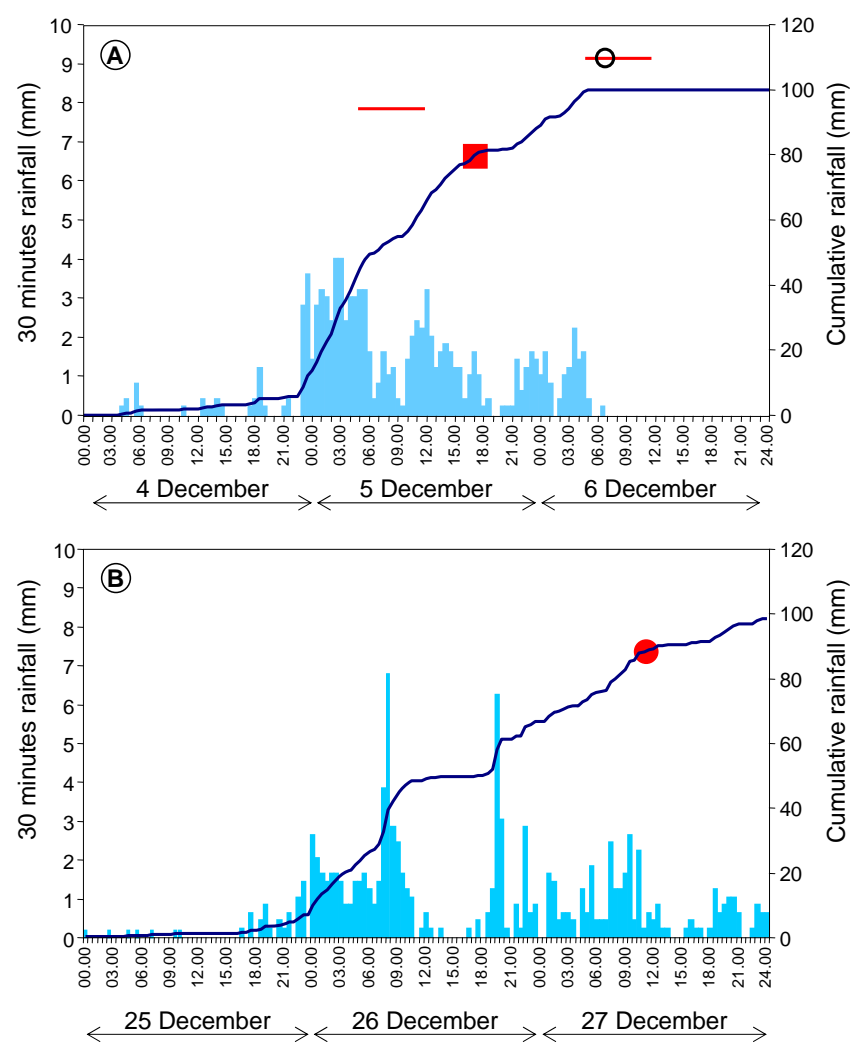

Fig. 9. Events rainfall history and timing of landslides. (A) 4-6 December 2004 event. (B) 25-27 December 2004 event. Vertical bars show $30 \mathrm{~min}$ cumulative rainfall. Blue lines show event cumulative rainfall. Periods of landslides are shown by horizontal red lines. Red dot shows exact timing of the Sugano soil slide - debris avalanche. Black circle shows approximate timing of the Badia and Podere Cipresso deep-seated landslide. Red square shows maximum discharge recorded along the Paglia River.

(Fig. 8d). From the Civil Protection Office of Orvieto (Comune di Orvieto, 2005) we obtained information on the date of occurrence of other seven landslides (and floods) (Table 3 and Fig. 6a).

Based on the collected information, during the 4-6 December 2004 rainfall event landslides began to occur in the early morning of 5 December, at an imprecise time (Fig. 9a). The slope failures were mostly minor soil slides and debris flows that caused damage to roads, particularly near Torre San Severo and Benano (2 and 3 in Table 3 and Fig. 6a), and $\mathrm{E}$ of Orvieto (1 in Table 3 and Fig. 6a). In the morning of 5 December, inundations along the Paglia River occurred between Ponte Giulio and Orvieto Scalo (4 and 5 in Table 3 and Fig. 6a). Peak discharge along the Paglia River was measured at the 16:00 on 5 December (red square in Fig. 9a). Deep seated and shallow landslides were reported also on 6 December, again at an imprecise time (6 and 7 in Table 3 and Fig. 6a). For the 25-27 December rainfall event, information on the time of failure is available only for a soil slide
- debris avalanche at Sugano ( 8 in Table 3 and Figs. $6 a$, b), which occurred at 11:15 on 27 December (red dot in Fig. 9b). Based on an eyewitness's account, the slope failure moved "almost instantaneously" (i.e., rapidly and without notice) from a very steep slope, incorporating vegetation, soil and debris.

\subsection{Correlation with rainfall}

Despite the scarcity of information on the exact (or even the approximate) time of landslides, we attempt a correlation between the rainfall history and the time of the slope failures. Figure 9 shows the rainfall measured at the Orvieto rain gauge for the period from 00:00 on 4 December to 24:00 on 6 December, and for the period from 00:00 on 25 December to $24: 00$ on 27 December. In Fig. 9, the 30 min rainfall (vertical bars) and the cumulative rainfall (continuous lines) are shown together with the reported time or periods of occurrence of landslides and inundations (Table 3 ).

Figure 9a shows that in the early morning of 5 December landslides began after about $6 \mathrm{~h}$ of intense rainfall, at the end of the first rainfall burst, and when the cumulative rainfall had exceeded about $50 \mathrm{~mm}$. Small, shallow landslides continued to occur throughout 6 December, with rainfall intensities of less than 2-3 mm in $30 \mathrm{~min}$. Peak discharge along the Paglia River was measured at the Ponte dell'Adunata gage at 16:00, when cumulative rainfall exceeded $80 \mathrm{~mm}$, but inundations had started in the morning of 5 December. The Badia and Podere Cipresso deep seated landslide (6 in Table 3 and Figs. 6a, d) and the Sugano soil slide - debris avalanche (7 in Table 3 and Figs. 6a, b) occurred at an imprecise time on 6 December (Fig. 9a), towards the end of the rainfall event, when the cumulative rainfall exceeded $90 \mathrm{~mm}$, corresponding to an average event intensity over a 30 -h period of about $3 \mathrm{~mm} / \mathrm{h}$. Figure $9 \mathrm{~b}$ shows that a second soil slide - debris avalanche at Sugano occurred at 11:15 on 27 December, at the end of the rainfall event. At this time the cumulative rainfall exceeded $90 \mathrm{~mm}$, for average event intensity over a 40-h period exceeding $2 \mathrm{~mm} / \mathrm{h}$.

Lack of precise information on the time of landslide occurrence impeded us from establishing a specific rainfall threshold for the initiation of shallow landslides in the Orvieto area. However, a few considerations can still be made. Inspection of Fig. 9a reveals that the first landslides to occur were the shallow slope failures, mostly soil slides and debris flows (1 to 3 in Table 3), which were apparently triggered by the highest rainfall intensity. The deep seated landslide (6 in Table 3) moved at the end of the rainfall event, well after the peak discharge was measured along the Paglia River. On 6 December, shallow landslides also occurred at the end of the rainfall event, and not as a result of a particularly intense single rainfall burst. The same occurred for the 25-27 December event, with the Sugano soil slide - debris avalanche failing at the end of the event, and not in correspondence with an intense rainfall period. We consider this an indication that the 

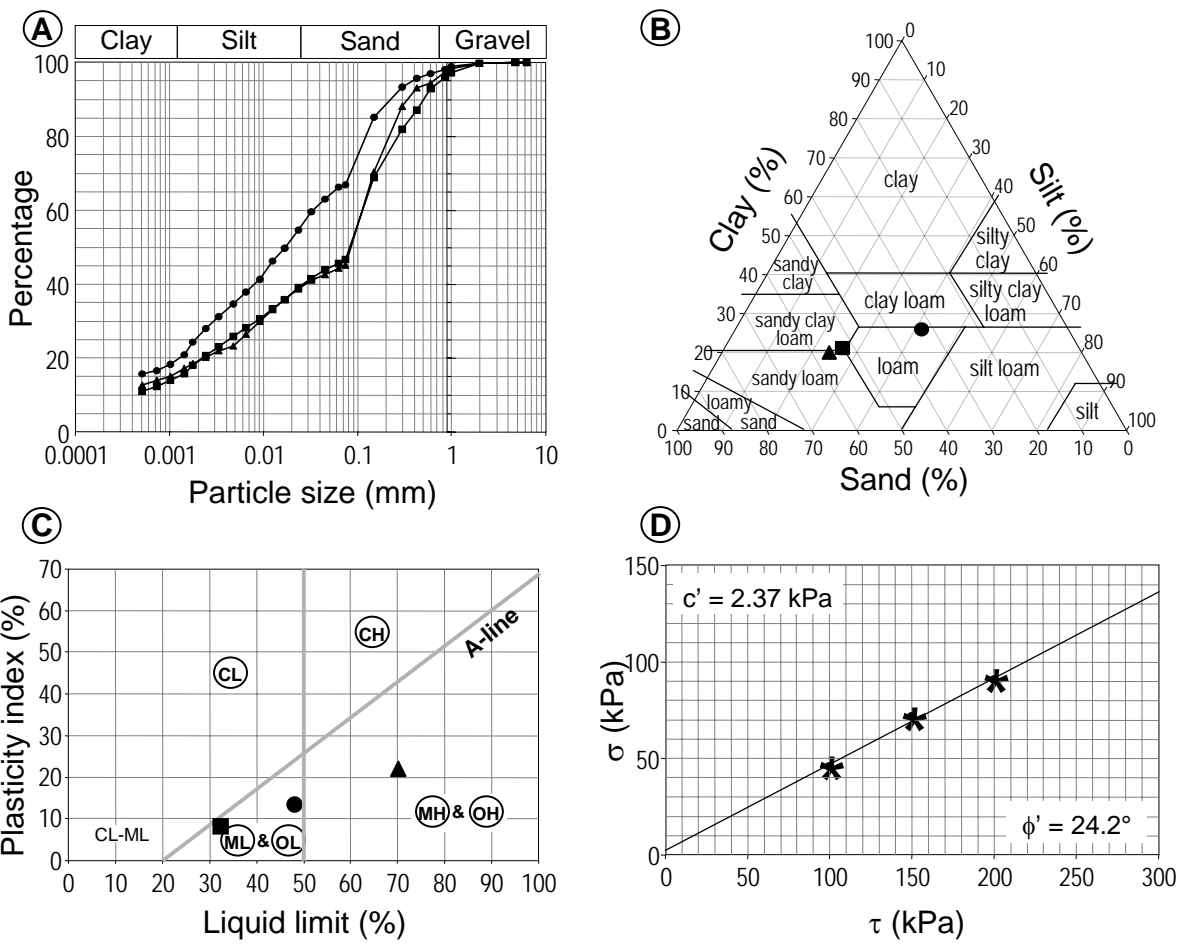

Fig. 10. Geotechnical characteristics of volcanic materials in the Orvieto area. Sample P1 (triangle) and P2 (circle) obtained in the head scarp of a large debris avalanche S of Porano (Fig. 6c). Sample S1 (square) obtained in the head scarp of a small soil slide - debris fall E of Sugano (Fig. 6b). (A) Granulometric curves. (B) Textural diagram. (C) Plasticity chart. (D) Results of consolidated, drained shear tests.

short-term (event) cumulative rainfall was important for the initiation of the shallow landslides in the Orvieto area. Analysis of the historical rainfall record ( $\$ 3.4$ and Fig. 5) has shown that the 3-month and the 4-month antecedent cumulative rainfall was also important for the initiation of landslides in the Orvieto area.

No clear spatial pattern for the rainfall induced landslides was observed in the Orvieto area. Landslides triggered by the 25-27 December event did not reactivate landslides initiated by the 4-6 December event.

\section{Geotechnical properties of weathered volcanic mate- rials}

We obtained general and site-specific geotechnical information on the failed volcanic materials through: (i) review of site specific investigations completed immediately after the landslide events to solve local instability conditions, and (ii) laboratory analyses conducted on three samples. We collected two samples (P1 and P2) in the head scarp of a large debris avalanche near Porano (Fig. 6c), and we obtained the third sample (S1) near the head scarp of a small soil slide debris fall W of Sugano (Fig. 6b). Samples were obtained using steal tubes $100 \mathrm{~mm}$ in diameter and $30 \mathrm{~cm}$ in length, inserted into the soil with a heavy hammer. On the three sam- ples we performed: (i) grain size analyses, (ii) determination of the Atterberg limits, and (iii) shear tests.

Grain size analyses were performed by sieving for grain particles in the range from $6.3 \mathrm{~mm}$ to $0.075 \mathrm{~mm}$, and by density settling for particle sizes smaller than $0.075 \mathrm{~mm}$ (ASTM standards). Inspection of the obtained grain-size distributions (Fig. 10a) indicates that the tested volcanic materials are poorly sorted, with abundance of particle sizes in the range from $0.3 \mathrm{~mm}$ to $0.075 \mathrm{~mm}$, i.e., from medium to fine grained sand. Textural analyses (Fig. 10b) indicate that the sampled volcanic materials range from sandy loam (P1 and $\mathrm{S} 1)$ to loam (S1). In the examined samples, clay content $(\phi \leq 0.002 \mathrm{~mm})$ ranged from $19 \%$, for sandy loam soils (P1 and $\mathrm{S} 1$ ), to $26 \%$, for loam soils (P2). We further tested the fine-grained part of the samples to determine the liquid limit (LL) and the plasticity index (PI). Results are listed in Table 4 and shown in Fig. 10c. According to the Unified Soil Classification system, the weathered volcanic materials are inorganic silty soils and organic soils of low compressibility (ML, OL) (P2 and S1), and inorganic silty soils and organic soils of high compressibility $(\mathrm{MH}, \mathrm{OH})(\mathrm{P} 1)$. Lastly, we performed consolidated and drained shear tests on a reconstructed sample (S1). The shear tests revealed a low value of cohesion (2.37 Kpa), and a friction angle of $24.2^{\circ}$ (Fig. 10d).

Table 4 summarizes the results of the performed laboratory tests, and compares the obtained values with published 
results of similar geotechnical investigations completed on volcanic soils in Campania Region, southern Italy (Celico et al., 1986; Guadagno, 1991; Guadagno and Magaldi, 2000; Aceto et al., 2003; Crosta and Dal Negro, 2003).

The grain-size distributions of the three examined samples (P1, P2, and S1, Fig. 10a) exhibit a large proportion of grains in the range from $0.08 \mathrm{~mm}$ to $0.3 \mathrm{~mm}$, and fall in the field of sediments defined as "in situ soils" by Guadagno (1991), who analysed in situ and reworked (by landslides) volcanoclastic soils in the Lattari and Piacentini mountain ranges, in Campania region. The grain-size distributions of our three samples are also in reasonable agreement with the grain-size distributions obtained by Guadagno and Magaldi (2000) and by Aceto et al. (2003), who examined volcanic soils in the source areas of the Braciliano, Episcopio, Quindici and Siano debris flows of 5-6 May 1998. Results of our grain-size analyses are slightly different from those obtained by Crosta and Dal Negro (2003), which also analysed volcanic soils in the head scarps of shallow slides that resulted in large debris flows in Campania region in 1998. Our analyses indicated that volcanic soils in the Orvieto area are finer in size than the in situ soils examined by Crosta and Dal Negro (2003). Inspection of Table 4 reveals that friction and cohesion values for the volcanic soils in the Campagna region are generally higher than the value obtained from the single, reconstructed sample taken at Sugano $\left(\phi^{\prime}=24.2^{\circ}, c^{\prime}=2.37 \mathrm{kPa}\right)$. The value of the friction angle measured for the Sugano soil (S1) is considerably smaller than the values given by Guadagno (1991) for reworked pyroclastic deposits in Campania region. The dry unit weight $\gamma_{d}$ of sample S1 is in the high range of values measured for volcanic materials in Campania region. We attribute this to the fine texture of the weathered volcanic materials at Sugano. Lastly, we note that the Plastic Limit (PL) and the Plasticity Index (PI) obtained for sample S1 are lower than the corresponding values for volcanic soils in Campania (Table 4).

\section{Landslide damage}

In the Orvieto area, landslides in December 2004 produced damage to the transportation network, local homes, and agriculture. We obtained information on landslide damage from different sources. The primary source of information was the Office of Civil Protection in Orvieto (Comune di Orvieto, 2005), which conducted systematic surveys to establish the location and the extent of landslide damage in the period from December 2004 to January 2005. We obtained additional information through field work conducted mostly along the roads, and by interviewing local residents. Table 5 summarizes our findings, and Fig. 11 shows examples of landslide damage in the Orvieto area.

Soil slides - debris avalanches were responsible for severe damage near Porano and Sugano. The large failures that occurred at Porano threatened a group of houses under construction (Fig. 7b). No direct damage was posed to the houses, but construction was halted, producing an indirect economic damage. In the Sugano village a soil slide - debris avalanche threatened a house and damaged a road (Fig. 11f). For safety reasons, the inhabitants were evacuated from the house, and the road was closed resulting in an indirect damage to the population. Soil slides - debris flows - debris and rock falls were responsible for damage to the transportation network (Figs. 8j, 11d, e). Due to these landslides, at least eleven roads were temporarily interrupted, and several others were endangered. Damage was caused by debris and muddy water that flowed over the roads (Figs. 11d, e). Rock falls and topples posed a threat to a farm road in the Sugano area (Fig. 8f), and to a building at Castel Rubello, W of Porano.

Deep seated landslides were responsible for damage to roads, and posed a threat to private homes, some of which had to be temporarily abandoned. The Badia and Podere Cipresso landslide (Figs. 11a, b) damaged a private road and threatened the stability of four buildings. For safety reasons, about 20 people were evacuated.

The Office of Civil Protection of Orvieto (Comune di Orvieto, 2005) attempted an estimate of the direct costs of the emergency actions and the remedial works. Figures are summarized in Table 5, and sum to EUR 150000 for emergency works, and to EUR 4770000 for completing the remedial works. We consider these figures as lower estimates of the total economic damage. The estimates were obtained mostly after the 4-5 December event, and do not consider: (i) all the sites damaged by landslides, (ii) damage produced by the 25-27 December rainfall event, (iii) the cost of local emergency works done by private citizens, (iv) damage to agriculture, and (v) indirect damage caused by the slope failures.

\section{Validation of a landslide risk assessment for the Sug- ano area}

In the framework of a national attempt to ascertain landslide risk in Italy (Gazzetta Ufficiale della Repubblica Italiana, 1998), in the period from 1999 to 2000 we assessed landslide hazards and risk in 79 villages in Umbria (Cardinali et al., 2002; Reichenbach et al., 2005). One of the investigated sites was the village of Sugano, where landslides were most numerous in December 2004 (Fig. 6b). The recent rainfall induced landslides provide a good opportunity to test the risk assessment prepared for the Sugano area. In this section, we briefly describe the methodology adopted to ascertain landslide hazards and risk in Umbria, we show the hazards and risk zoning prepared for the Sugano village, and we compare the hazard zoning and the risk assessment with the December 2004 rainfall-induced landslides in the Sugano area. Based on the obtained results, we prepare a new landslide risk assessment for Sugano village. 
Table 4. Geotechnical properties of volcanic materials in the Orvieto area and in Campania Region, southern Italy. Samples P1 and P2 obtained in the head scarp of a large debris avalanche S of Porano (Fig. 6c). Sample S1 obtained in the head scarp of a small soil slide debris fall E of Sugano (Fig. 6b). $\gamma$, natural unit weight; $\gamma_{S}$, weight of grains; $\gamma_{d}$, dry unit weight; $w$, Water content; LL, Liquid limit; PL, Plasticity limit; PI, Plasticity index; CI, Consistency index; $\phi^{\prime}$ friction angle (peak); $\phi_{r}^{\prime}$ friction angle (residual); $c$, cohesion.

\begin{tabular}{|c|c|c|c|c|c|c|c|c|c|c|c|c|}
\hline & Area & $\begin{array}{l}\gamma \\
\mathrm{kN} / \mathrm{m}^{3}\end{array}$ & $\begin{array}{l}\gamma_{S} \\
\mathrm{kN} / \mathrm{m}^{3}\end{array}$ & $\begin{array}{l}\gamma_{d} \\
\mathrm{kN} / \mathrm{m}^{3}\end{array}$ & $\begin{array}{l}w \\
\%\end{array}$ & $\begin{array}{l}\mathrm{LL} \\
\%\end{array}$ & $\begin{array}{l}\text { PL } \\
\%\end{array}$ & PI & $\mathrm{CI}$ & $\begin{array}{l}\phi^{\prime} \\
\circ\end{array}$ & $\phi_{r}^{\prime}$ & $\begin{array}{l}c \\
\mathrm{kPa}\end{array}$ \\
\hline This work (P1, Porano) & Orvieto & & 24.70 & & 62.98 & 69.82 & 47.75 & 22.07 & 0.31 & & & \\
\hline This work ( $\mathrm{P} 2$, Porano) & Orvieto & & 25.28 & & 39.06 & 47.07 & 32.67 & 14.40 & 0.56 & & & \\
\hline This work (S1, Sugano) & Orvieto & 16.37 & 25.58 & 12.74 & 27.95 & 34.00 & 26.01 & 7.99 & 0.73 & 24.2 & & 2.37 \\
\hline Celico et al. (1986) & Campania & & & $10-15$ & & & & & & $31-36$ & & $0-20$ \\
\hline Guadagno (1991) & Campania & & & $9-13$ & $20-30$ & & & & & $34-40$ & & \\
\hline Guadagno and Magaldi (2000) & Campania & & & $6.6-10.5$ & $14.0-70.1$ & $42.7-82.4$ & $47.0-58.9$ & $12.8-27.6$ & & 35 & $27-29$ & 20 \\
\hline Scotto di Santolo et al. (2000) & Campania & & & $10.0-13.5$ & & & & & & & $32-35.5$ & $3-13$ \\
\hline Aceto et al. (2003) & Campania & $10-14$ & $23.5-25.8$ & $6-10$ & & & & & & $33-35$ & & $3-5$ \\
\hline Crosta and Dal Negro (2003) & Campania & & & $7.2-9.9$ & & $39-78$ & & & & $35.5-44.9$ & $35.0-41.2$ & $0-34$ \\
\hline
\end{tabular}

Table 5. Landslide damage in the Orvieto area. Site information and economic damage from Office of Civil Protection of Orvieto (Comune di Orvieto, 2005) and from surveys conducted for this work.

\begin{tabular}{|c|c|c|c|c|c|c|}
\hline \multirow[t]{2}{*}{ Landslide site } & \multirow{2}{*}{$\begin{array}{l}\text { Buildings } \\
\#\end{array}$} & \multirow{2}{*}{$\begin{array}{l}\text { Roads } \\
\#\end{array}$} & \multirow{2}{*}{$\begin{array}{l}\text { People } \\
\#\end{array}$} & \multirow[t]{2}{*}{ Types of damage } & \multicolumn{2}{|c|}{ Economic damage (EUR) } \\
\hline & & & & & Emergency & Repair \\
\hline $\begin{array}{l}\text { Badia and Podere Cipresso } \\
\text { (Figs. } 6 \mathrm{~d}, 8 \mathrm{k}, 11 \mathrm{a}, \mathrm{d})\end{array}$ & 4 & 1 & $\sim 20$ & $\begin{array}{l}\text { Stability of houses threatened, damage to a farm house, } \\
\text { failure of minor retaining walls, ground deformations, } \\
\text { road temporarily interrupted. }\end{array}$ & 35000 & 1200000 \\
\hline $\begin{array}{l}\text { Sugano, municipality road "delle } \\
\text { Scalette" (Fig. 11f). }\end{array}$ & 2 & 1 & $\sim 10$ & $\begin{array}{l}\text { Stability of houses threatened, ground deformations, minor road } \\
\text { interrupted. }\end{array}$ & 50000 & 3500000 \\
\hline $\begin{array}{l}\text { Sugano, homes along the volcanic } \\
\text { escarpment. }\end{array}$ & 5 & & $\sim 30$ & Stability of houses threatened, ground deformations. & undetermined & undetermined \\
\hline $\begin{array}{l}\text { Porano, homes under construction } \\
\text { along the volcanic escarpment } \\
\text { (Fig. } 7 \text { b). }\end{array}$ & 1 & & & $\begin{array}{l}\text { Stability of a house threatened, ground deformations, construction } \\
\text { halted. }\end{array}$ & & undetermined \\
\hline Porano, local police headquarters & 1 & & $\sim 20$ & Stability of a house threatened. & & undetermined \\
\hline $\begin{array}{l}\text { Various provincial, municipal, and } \\
\text { farm roads. }\end{array}$ & & 12 & $\sim 1000$ & $\begin{array}{l}\text { Several roads interrupted due to slope failures, mostly from road } \\
\text { cuts. }\end{array}$ & 65000 & 70000 \\
\hline Total & & & $\sim 1080$ & & 150000 & 4770000 \\
\hline
\end{tabular}

8.1 Geomorphological approach to the definition of landslide risk

In 1999, we devised a methodology to assess landslide hazards and risk at site scale (Cardinali et al., 2002; Reichenbach et al., 2005). The method was based on the interpretation of multiple sets of aerial photographs, combined with the analysis of site-specific and historical information, and requires the careful scrutiny of the "state of nature", i.e., of all the existing and past landslides that can be identified in the study area. Based on the observed changes in the distribution and pattern of landslides, the possible short term evolution of the slopes, the probable type of failures and their expected frequency of occurrence are ascertained. The obtained information is used to estimate the landslide hazards and to evaluate the associated risk.

The methodology, described in detail by Cardinali et al. (2002) and Reichenbach et al. (2005), involves multiple steps, including: (i) the definition of the extent of the study area, constituted by one or more "elementary slopes", i.e., terrain units bounded by drainage and divide lines, (ii) the preparation of a multi-temporal landslide inventory map through the systematic analysis of aerial photographs of different dates and field surveys, including classification of landslides into slow moving (e.g., slides and flows), rapid moving (e.g., debris flows), and extremely rapid moving (e.g., rock falls) failures, (iii) the outline of one or more landslide hazard zone (LHZs), defined as areas of possible (or probable) short-term evolution of an existing landslide, or a group of landslides of similar characteristics (i.e., type, volume, depth, velocity), (iv) the assessment of landslide hazards, considered a function of the estimated frequency of landslide movements and of the expected landslide intensity (i.e., of landslide volume and velocity), (v) the identification and mapping of the elements at risk, including the population, and the assessment of their vulnerability to different landslide types, and (vi) the evaluation of specific and total landslide risk. 

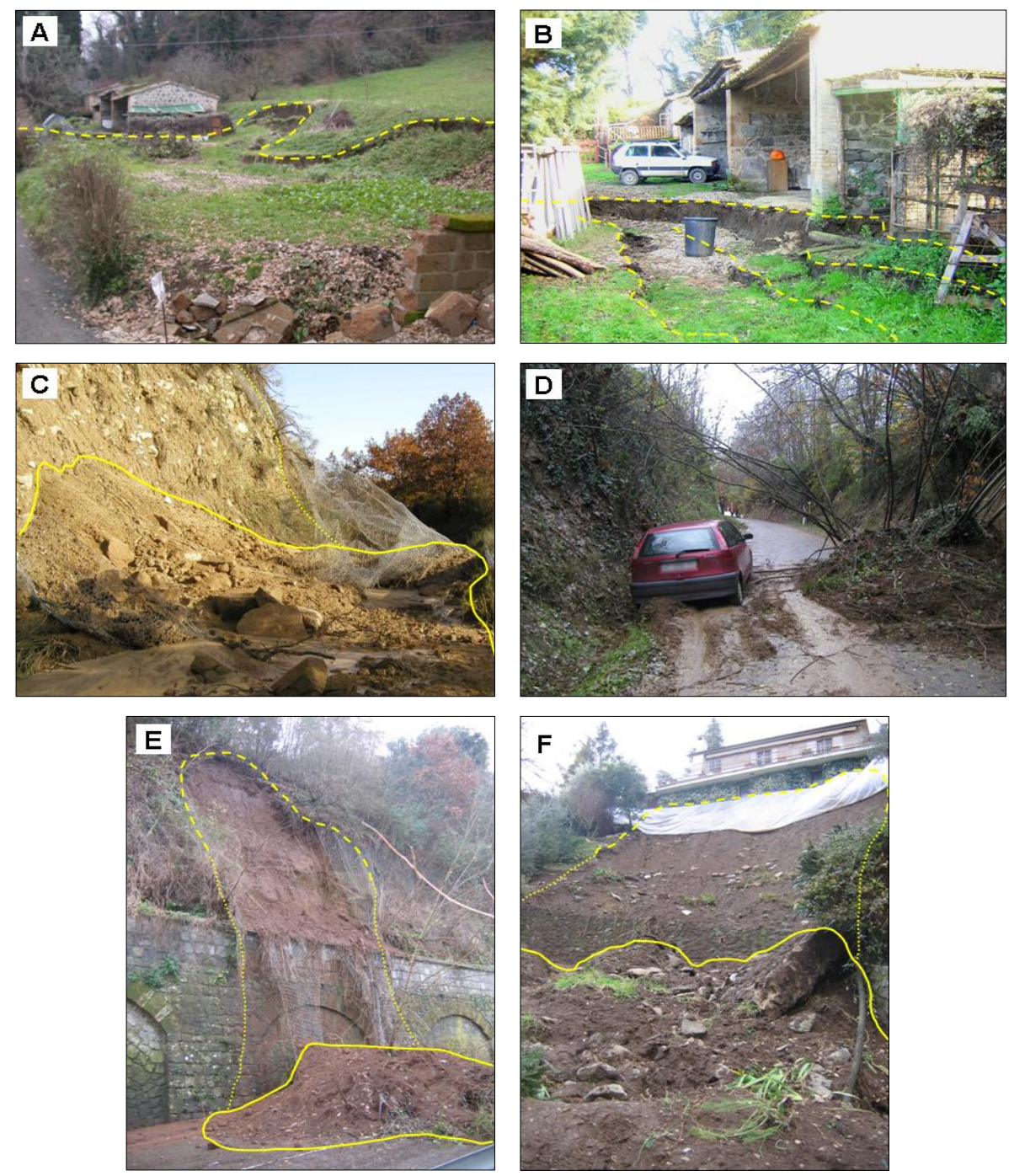

Fig. 11. Examples of damage caused by rainfall-induced landslides in December 2004 in the Orvieto area. Dashed yellow line shows source area, dotted yellow line shows travel area, continuous yellow line shows deposition area. (A) and (B) Badia and Podere Cipresso deep-seated translational slide; figures show ground deformations, damage to a farm house and to a farm road. (C) Debris flow deposit along the Corbara road; damage consisted in interruption of the road. (D) Debris flow along road, which was temporarily interrupted. (E) Soil slide - debris avalanche, which partly interrupted a road. (F) Soil slide - debris avalanche at Sugano; the figure shows a house threatened by the slope failure and the landslide material deposited on the "Le Scalette" road, which was interrupted. Panels (A) to (D) courtesy of Civil Protection Office of Orvieto.

The methodology relies on a set of empirical correlation tables, which are used to define landslide frequency and intensity, to ascertain landslide hazard, to evaluate the expected damage to the vulnerable elements, and to attribute levels of specific and total landslide risk (Cardinali et al., 2002; Reichenbach et al., 2005). Landslide hazard and specific landslide risk are expressed using a multiple-digit positional index that shows all the variables used to ascertain landslide hazard and risk, i.e., intensity, frequency and vulnerability (Cardinali et al., 2002; Reichenbach et al., 2005).

\subsection{Risk assessment for the Sugano village}

Figures 12a-d show the landslide hazard zoning prepared for the Sugano village by Reichenbach et al. (2005). Through the analysis of three sets of aerial photographs taken in September 1954 at 1:33000 scale, in June 1977 at 1:13000 scale, and in March 1994 at 1:36000 scale, supplemented by field reconnaissance in May 2000, four landslide types were identified in the Sugano area, namely (i): extremely rapid landslides, rock falls, topples and rock slides (Fig. 12a), (ii) slow-moving, shallow rotational and translational slides and slide earth-flows (Fig. 12b), (iii) slow-moving, deep seated 

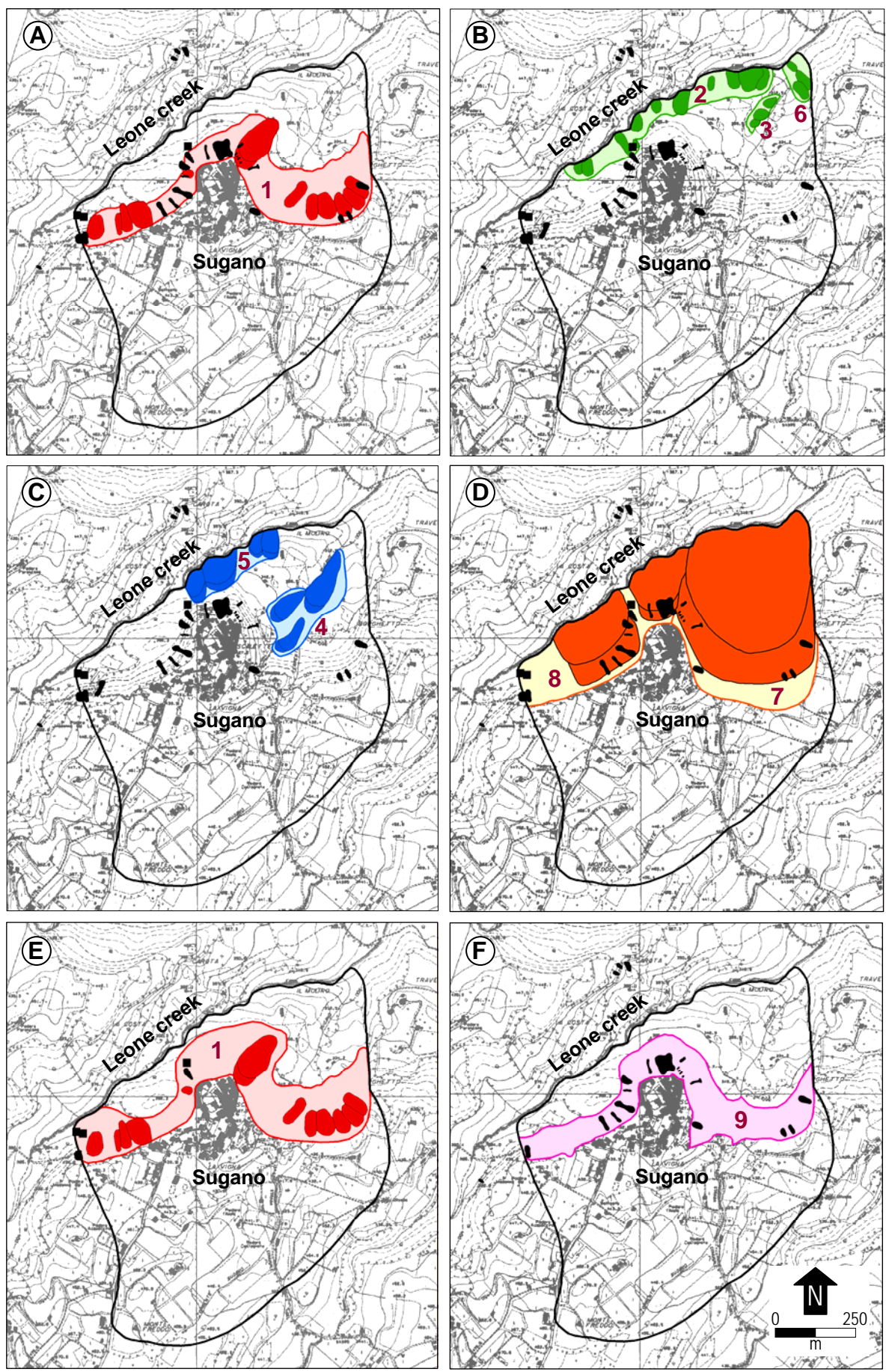

Fig. 12. Maps show December 2004 rainfall-induced landslides (black), pre-existing landslides (dark colours), and landslide hazard zones (LHZs) (light colours) for different types of mass movements. Thick black line portrays extent of the single "elementary slope" identified in the study area. Numbers indicate location of LHZs listed in Tables 5 and 6. Maps (A) to (D) show LHZs defined by Reichenbach et al. (2005) for four landslide types: (A) extremely rapid landslides rock falls, topples and rock slides (red), (B) slow-moving, shallow rotational and translational slides and slide earth-flows (green), (C) slow-moving, deep seated slides and slide earth-flows (blue), (D) slow-moving, very large and relict deep-seated block slides (orange). Map (E) shows updated LHZ for extremely rapid rock falls and topples (Table 7). Map (F) shows new LHZ for rapid to very rapid shallow landslides, including soil slides, debris flows and debris avalanches (Table 7). 
slides and slide earth-flows (Fig. 12c), and (iv) slow-moving, very large and relict deep-seated block slides (Fig. 12d). A single large LHZ was identified for extremely rapid rock falls, topples and rock slides which erode the volcanic cliff, endangering the houses located at the edge of the escarpment (1 in Fig. 12a). Three LHZs were identified for slow-moving shallow rotational and translational slides and slide earthflows (2, 3 and 6 in Fig. 12b), which were mapped primarily in the deposit of pre-existing, deep seated landslides. Two LHZs were mapped for slow-moving, deep-seated slides and slide earth-flows (4 and 5 in Fig. 12c) also recognized in the marine clays. Two LHZs were defined for the relict, deepseated block slides (7 and 8 in Fig. 12d), which were recognized in the marine clays underlying the volcanic rocks.

To ascertain landslide risk, information on the location and type of the vulnerable elements is necessary. Figures 13a-d show the distribution and type of elements at risk in the Sugano area. Four types of elements were considered, namely: (i) build-up areas with high population density (HD); (ii) build-up areas with low population density and scattered houses (LD); (iii) secondary roads (SR), and (iv) farm roads and other minor roads (FR) (Reichenbach et al., 2005).

By combining the landslide hazard zonings (Figs. 12a-d) and the information on the vulnerable elements (Figs. 13ad), specific and total risk levels were determined (Reichenbach et al., 2005). Results area listed in Table 6. Based on the established terrain subdivisions, on the available information on the type, abundance and frequency of historical mass-movements, and on the location and type of the vulnerable elements, landslide risk in the Sugano area was estimated as very high where rock falls, topples and rock slides were expected, mostly along and down slope from the volcanic escarpment (1 in Table 6 and Fig. 12a). In these areas casualties and structural damage to houses and minor roads was considered possible (Table 6). Where sparse houses and farms were affected by deep seated slides of medium intensity, landslide risk was considered high (4 and 5 in Table 6 and Fig. 12c). Where low-density settlements and minor roads were affected by shallow landslides, risk was ascertained medium (2, 3 and 6 in Table 6 and Fig. 12b). Finally, where the relict deep-seated block-slides were mapped, landslide risk was ascertained low (7 and 8 in Table 6 and Fig. 12d), because reactivation of the entire landslides was not considered likely under the present climatic and seismic conditions (Reichenbach et al., 2005).

\subsection{Comparison with the recent rainfall induced landslides}

The maps shown in Fig. 12 show the location and abundance of the rainfall induced landslides in December 2004 (black areas). This information allows for a comparison with the existing hazards and risk assessment prepared for Sugano (Table 6 and Fig. 12). In the Sugano area, intense rainfall did not result in deep-seated block-slides, in slow-moving deep-seated rotational and translational slides, or in slow- moving shallow landslides. Thus, the three corresponding landslide scenarios (Figs. 12b, c, d) cannot be validated. However, a few deep-seated translational slides, and several slow-moving shallow landslides occurred at other sites in the Orvieto area, locally causing significant damage (e.g., Figs. 11a, b). We consider this an indication that slow moving, deep seated and shallow landslides can occur in the Sugano area, particularly where marine sediments crop out, and we maintain the existing hazard scenarios (Figs. 12a, c, d) and the associated risk assessments ( 2 to 8 in Table 6).

In the Sugano area, the recent rainfall resulted in rapid to extremely rapid shallow failures. Extremely rapid landslides, including rock falls, topples and minor rock slides, were predicted by the landslide hazards and risk assessment prepared for Sugano (Fig. 12a, 1 in Table 6). Comparison between the extents of the LHZ for extremely rapid failures and the location of the recent rock and debris falls reveals that all the falls initiated inside the single LHZ defined for extremely rapid landslides (1 in Fig. 12a), and that most of the fallen landslide material was deposited inside the same LHZ. However, three individual rock fall boulders (black squares in Fig. 12a) travelled outside the LHZ, indicating that the geomorphological criteria used to define the maximum travel distance of rock falls was insufficient to precisely determine the rock fall hazard locally.

Several of the recent rainfall induced landslides in the Sugano area were shallow, rapid slides, flows, and avalanches involving loose soil and natural and man made debris. These failures were not predicted by the hazards and risk assessment prepared for Sugano. This was a limitation. We investigated the reasons for the failure in recognizing the rapid shallow landslides. Shallow soil slides and flows on steep slopes leave only small and superficial empty scars, which are quickly covered by vegetation. The failed material deposited at the base of the escarpment was loose, easily removable by rainfall or surface runoff, or reworked and displaced by human actions. Thus, persistence of the morphological features that allows recognizing the shallow slides and flows is limited, making it hard to recognize old shallow landslides from the aerial photographs or in the field. Field surveys conducted in the Sugano area in July 2005, a period when vegetation was particularly abundant along and at the base of the volcanic escarpment, confirmed the difficulty in recognizing and mapping some of the shallow landslides occurred only a few months before the survey.

Due to the steepness of the slopes along the volcanic escarpment, shallow landslides involving soil and debris were rapid to extremely rapid failures. We can attempt a comparison between the location of the shallow slope failures and the landslide scenario originally proposed for the extremely rapid landslides, i.e., for rock falls (Fig. 12a). The comparison is significant because some of the shallow slope failures exhibited a fall component. The comparison between the extents of the LHZ for extremely rapid failures and the location of the shallow failures (slides, flows, and avalanches 

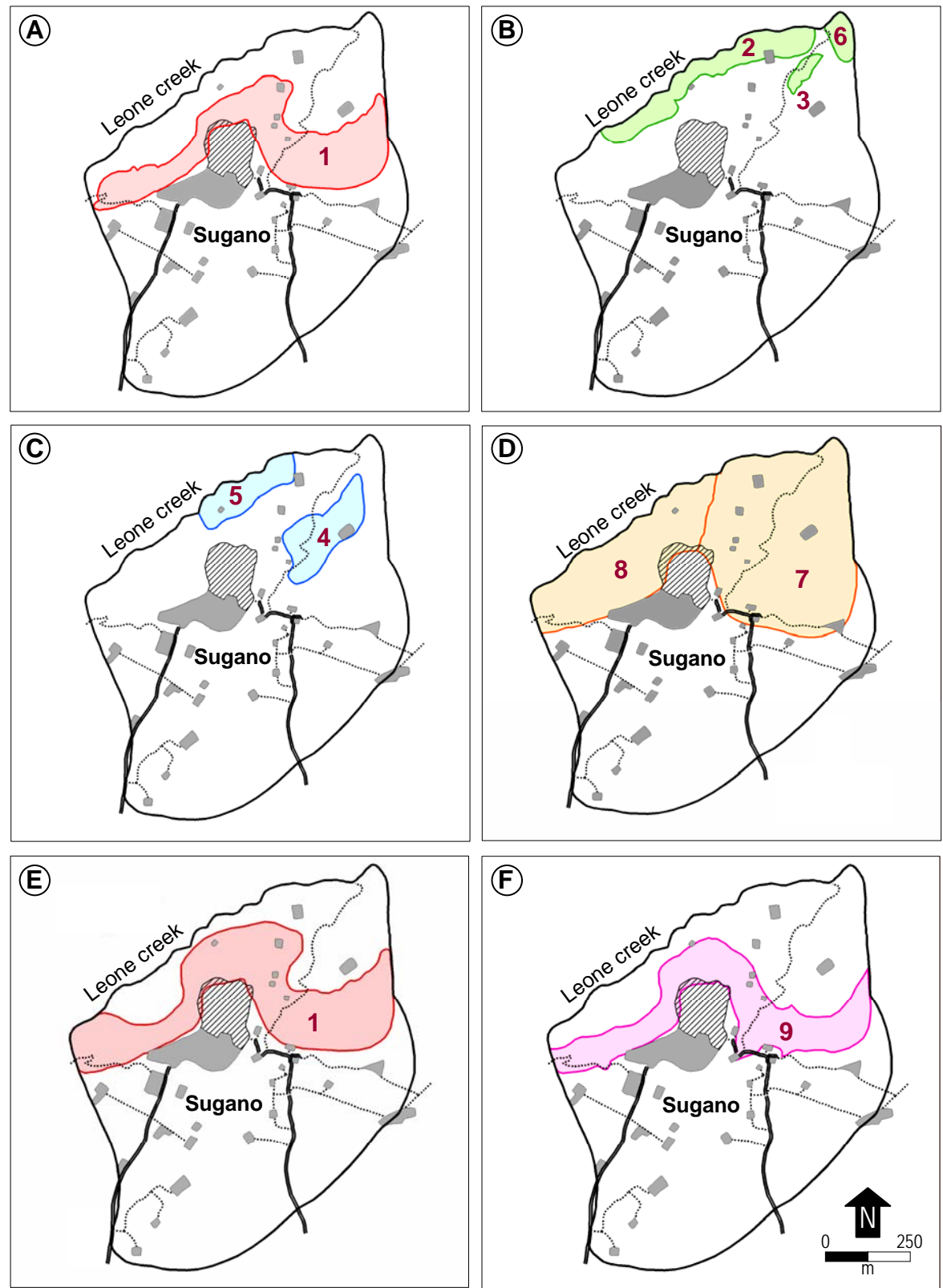

Fig. 13. Distribution and types of elements at risk in the Sugano area. Legend: Oblique grey pattern=built up areas with high population density (HD), solid grey=built up areas with low population density and scattered houses (LD), thick black line=secondary road (SR), thin dotted line=farm road or minor road (FR). Coloured polygons show LHZs for different landslide types. Numbers indicate location of LHZs listed in Tables 6 and 7. Maps (A) to (D) show LHZs defined by Reichenbach et al. (2005) for: (A) extremely rapid rock falls (red), (B) slow-moving, shallow landslides (green), (C) old and recent, slow-moving deep-seated slides (blue), (D) very old (relict) slow-moving deepseated landslides (orange). Map (E) shows updated LHZ for extremely rapid rock falls, topples and rock slides (Table 7). Map (F) shows new LHZ for rapid to very rapid shallow landslides, including soil slides, debris flows and debris avalanches (Table 7).

involving volcanic soil and debris) reveals that most of the landslides initiated on soil or debris at or close to the edge of the volcanic escarpment, i.e., inside the LHZ for extremely rapid failures (Fig. 12a). Further inspection reveals that all the landslide material transported by shallow slope failures was deposited inside the LHZ delimited for the extremely rapid failures.

\subsection{New landslide hazards and risk assessment for Sugano}

Based on the event inventory of rainfall-induced landslides in the Sugano area, and on the critical evaluation of the performance of the existing hazard assessment and the associated risk scenarios, we have updated the landslide hazards and risk assessment for Sugano. The new assessment contains: 
Table 6. Sugano area (Fig. 6b). Original classification of specific, $\mathrm{R}_{S}$, and total, $\mathrm{R}_{T}$, landslide risk (Reichenbach et al., 2005). LHZ, landslide hazard zone. $\mathrm{F}_{L}$, landslide frequency in 3 classes: 1=low, $2=$ medium, $3=$ high. $\mathrm{I}_{L}$, landslide intensity in 4 classes: $1=$ slight, $2=$ medium, 3 =high, $4=$ very high. $\mathrm{H}_{L}$, landslide hazard shown using positional index that expresses hazard as the combination of landslide intensity (right digit) and landslide frequency (left digit). E, type of element at risk, $\mathrm{HD}=$ built up areas with a high population density, $\mathrm{LD}=$ built up areas with a low population density and scattered houses, $\mathrm{SR}=$ secondary road, $\mathrm{FR}=$ farm and minor road. V, expected vulnerability of the elements at risk: $\mathrm{A}=$ aesthetic or minor damage, $\mathrm{F}=$ functional or medium damage, $\mathrm{S}=$ structural or total damage. $\mathrm{P}$, vulnerability of population: $\mathrm{D}=$ direct damage, $\mathrm{I}=$ indirect damage, $\mathrm{H}=$ homeless people. Specific risk expressed as a combination of landslide hazard (right and central digits) and landslide vulnerability (left digit).

\begin{tabular}{|c|c|c|c|c|c|c|c|c|c|}
\hline LHZ \# & Landslide Type & $\mathrm{F}_{L}$ & $\mathrm{I}_{L}$ & $\mathrm{H}_{L}$ & $\mathrm{E}$ & $\mathrm{V}$ & $\mathrm{P}$ & $\mathrm{R}_{S}$ & $\mathrm{R}_{T}$ \\
\hline \multirow{6}{*}{1} & \multirow{6}{*}{ Rock fall } & & & & HD & $\mathrm{S}$ & $\mathrm{D}, \mathrm{H}$ & S 33 & \multirow{3}{*}{ Very High } \\
\hline & & 3 & 3 & 33 & LD & $\mathrm{S}$ & $\mathrm{D}, \mathrm{H}$ & S 33 & \\
\hline & & & & & FR & $\mathrm{S}$ & $\mathrm{D}$ & S 33 & \\
\hline & & \multirow{3}{*}{1} & \multirow{3}{*}{4} & \multirow{3}{*}{14} & HD & $S$ & $\mathrm{D}, \mathrm{H}$ & S 14 & \multirow{3}{*}{ Very High } \\
\hline & & & & & LD & S & $\mathrm{D}, \mathrm{H}$ & S 14 & \\
\hline & & & & & FR & $\mathrm{S}$ & D & S 14 & \\
\hline 2 & Shallow slide & 3 & 1 & 31 & $\mathrm{LD}$ & A & $\mathrm{N}$ & A 31 & Medium \\
\hline 3 & Shallow slide & 2 & 1 & 21 & FR & $\mathrm{S}$ & $\mathrm{N}$ & S 21 & Medium \\
\hline \multirow{2}{*}{4} & \multirow{2}{*}{ Deep-seated slide } & \multirow[b]{2}{*}{1} & \multirow{2}{*}{2} & \multirow{2}{*}{12} & LD & $\mathrm{F}$ & $\mathrm{H}$ & F 12 & \multirow{2}{*}{ High } \\
\hline & & & & & FR & $\mathrm{S}$ & $\mathrm{N}$ & S 12 & \\
\hline 5 & Deep-seated slide & 1 & 2 & 12 & LD & $\mathrm{F}$ & $\mathrm{H}$ & F 12 & High \\
\hline 6 & Shallow slide & 1 & 1 & 11 & FR & $S$ & $\mathrm{I}, \mathrm{H}$ & S 11 & Medium \\
\hline \multirow{4}{*}{7} & \multirow{4}{*}{ Very old, deep seated slide } & \multirow{4}{*}{1} & \multirow{4}{*}{4} & \multirow{4}{*}{14} & HD & $\mathrm{S}$ & $\mathrm{I}, \mathrm{H}$ & S 14 & \multirow{4}{*}{ Low } \\
\hline & & & & & LD & $\mathrm{S}$ & $\mathrm{I}, \mathrm{H}$ & S 14 & \\
\hline & & & & & SR & S & I & S 14 & \\
\hline & & & & & FR & $\mathrm{S}$ & $\mathrm{N}$ & S 14 & \\
\hline \multirow{3}{*}{8} & \multirow{3}{*}{ Very old, deep seated slide } & \multirow{3}{*}{1} & \multirow{3}{*}{3} & \multirow{3}{*}{13} & HD & $\mathrm{S}$ & $\mathrm{I}, \mathrm{H}$ & S 13 & \multirow{3}{*}{ Low } \\
\hline & & & & & LD & $\mathrm{S}$ & $\mathrm{I}, \mathrm{H}$ & S 13 & \\
\hline & & & & & FR & $\mathrm{S}$ & $\mathrm{N}$ & S 13 & \\
\hline
\end{tabular}

(i) an updated scenario for extremely rapid shallow failures, mostly falls (Fig. 12e, 1 in Table 7), and (ii) a new scenario for rapid to very rapid shallow landslides, including soil slides, debris flows and debris avalanches (Fig. 12f, 9 in Table 7).

With respect to the previous scenario (Fig. 12a), which extended for $1.43 \times 10^{5} \mathrm{~m}^{2}$, the new scenario for extremely rapid falls (Fig. 12e) covers a larger portion of the low gradient slope at the base of the volcanic escarpment $\left(1.80 \times 10^{5} \mathrm{~m}^{2}, 25 \%\right.$ more territory). The enlargement considers the possibility of individual boulders bouncing or rolling further along the slope. The new scenario for rapid to very rapid shallow landslides (Fig. 12f) extends for $1.28 \times 10^{5} \mathrm{~m}^{2}$, and considers the possibility that failures can initiate mostly as soil slips in the weathered soils and in the natural and man made debris at the head of the volcanic escarpment. In this scenario, the landslide material travels at sustained speed along the steep slope, and deposits at the base of the cliff where it forms debris cones.
Maps shown in Figs. 12e and $\mathrm{f}$ show the location and type of the vulnerable elements in the updated (1) and in the new (9) LHZs. Table 7 lists the updated and new specific and total landslide risk assessment for Sugano, for extremely rapid rock falls, topples and rock slides (1), and for rapid to very rapid soil slides, debris flows and debris avalanches (9). Based on the updated and the new scenarios, we confirm that in the Sugano area total landslide risk is very high where extremely rapid rock falls, topples and rock slides are expected, mostly along and down slope from the volcanic escarpment. We further consider total landslide risk very high where rapid to very rapid shallow landslides are expected along the volcanic escarpment. In these areas casualties and structural damage to houses, urban roads and minor farm roads are possible (Table 7). 
Table 7. Sugano area (Fig. 6b). New and updated classification of specific landslide risk, $\mathrm{R}_{S}$, and of total landslide risk, $\mathrm{R}_{T}$. See Table 6 for explanation of symbols. See text for explanation.

\begin{tabular}{|c|c|c|c|c|c|c|c|c|c|}
\hline LHZ\# & Landslide type & $\mathrm{F}_{L}$ & $\overline{\mathrm{I}_{L}}$ & $\mathrm{H}_{L}$ & $\mathrm{E}$ & $\mathrm{V}$ & $\mathrm{P}$ & $\mathrm{R}_{S}$ & $\mathrm{R}_{T}$ \\
\hline \multirow{6}{*}{1} & \multirow{6}{*}{$\begin{array}{l}\text { Extremely rapid shallow failures } \\
\text { (rock fall, topple, and minor rock slide) }\end{array}$} & & & & HD & $\mathrm{S}$ & $\mathrm{D}, \mathrm{H}$ & $\mathrm{S} 43$ & \multirow{3}{*}{ Very high } \\
\hline & & 4 & 3 & 43 & LD & $\mathrm{S}$ & $\mathrm{D}, \mathrm{H}$ & S 43 & \\
\hline & & & & & FR & S & D & S 43 & \\
\hline & & \multirow{3}{*}{1} & \multirow{3}{*}{4} & \multirow{3}{*}{14} & HD & $\mathrm{S}$ & $\mathrm{D}, \mathrm{H}$ & S 14 & \multirow{3}{*}{ Very high } \\
\hline & & & & & LD & $\mathrm{S}$ & $\mathrm{D}, \mathrm{H}$ & S 14 & \\
\hline & & & & & FR & $\mathrm{S}$ & $\mathrm{D}$ & S 14 & \\
\hline \multirow{4}{*}{9} & \multirow{4}{*}{$\begin{array}{l}\text { Rapid to very rapid shallow failures } \\
\text { (soil slide - debris flow - debris and rock fall, } \\
\text { soil slide - debris avalanche) }\end{array}$} & \multirow{4}{*}{1} & \multirow{4}{*}{2} & \multirow{4}{*}{12} & HD & $\mathrm{S}$ & $\mathrm{D}, \mathrm{H}$ & $\mathrm{S} 12$ & \multirow{4}{*}{ Very high } \\
\hline & & & & & LD & $\mathrm{S}$ & $\mathrm{D}, \mathrm{H}$ & S 12 & \\
\hline & & & & & FR & $\mathrm{S}$ & D & $\mathrm{S} 12$ & \\
\hline & & & & & SR & $\mathrm{S}$ & D & $\mathrm{S} 12$ & \\
\hline
\end{tabular}

\section{Discussion}

In the Orvieto area, intense rainfall in December 2004 resulted in both deep seated and shallow landslides. Large, deep seated landslides were a minority, and were mainly translational movements involving marine sediments, chiefly clay and silt and subordinately sand and gravel. Deep-seated translational landslides are typical of marine sediments that crop out in south-western Umbria (Guzzetti et al., 1996; Reichenbach et al., 2005). Shallow slope failures were more numerous, and exhibited a larger variability of the types of movement. Soil slides, debris flows and mud flows that originated from the soils mantling the marine sediments, from the softened cover of deep seated landslides, and from badlands and other surface erosion areas where clay and silt crop out, are also typical for south-western Umbria (Guzzetti et al., 1996; Reichenbach et al., 2005).

Less well known (and for this reason less expected) were the shallow, rapid to very rapid slope failures which occurred along the escarpment that rims the volcanic deposits in the Orvieto area (Fig. 2) (Guzzetti et al., 1996). Based on the previously available information, particularly unexpected were the soil slides, debris flows and debris avalanches that originated from loose soils and debris at the edge of the volcanic escarpment. Due to their limited morphological expression, and due to the fact that they occur on very steep and forested slopes, these shallow landslides are difficult to recognize from the aerial photographs or in the field. This is important information that shows that landslide hazards and risk assessments prepared using incomplete landslide data may be erroneous. It also outlines the importance of preparing detailed landslide event inventories, and to update existing inventory maps when new landslides occur.

Landslides affecting the volcanic escarpment originated mostly from the upper part of the slope, from loose soil, from natural and man made debris, and subordinately from hard layers of volcanic rocks (e.g., basalt, pyroclastic deposit) present at different heights along the escarpment. The type of movement depended on the local morphology. Most of the landslides originated as soil slides and evolved differently depending on the geometry of the slope. Where slope was regular, planar and (mostly) rectilinear (e.g., Fig. 7b) the soil slides evolved into debris avalanches. Where slope was sub-vertical, vertical or overhanging - most commonly due to the presence of a layer of basalt or a hardened pyroclastic deposit - the soil slide turned into fall (e.g., Fig. 7a). Where an incision or a channel was present along the steep slope, most commonly towards the base of the escarpment, the failed material turned into a debris flow. Rock falls originated from pockets of coarse debris, or from the hard layers, as primary or secondary failures (Fig. 7c). Primary rock falls originated from the sliding or toppling of single or multiple blocks ranging in volume from a few cubic decimetres to a few cubic meters. Secondary rock falls resulted from the eroding effect of soil slides, debris avalanches and debris flows sliding or flowing over fractured basalt layers.

Shallow landslides along the escarpment that rims the volcanic cap in the Orvieto area were particularly abundant at Sugano (Fig. 6b). This may indicate a peculiar geographical concentration of the rainfall. However, such concentration cannot be established with the available rain gauge network. The existing meteorological network in Umbria has a density of about one rain gauge every $\sim 100 \mathrm{~km}^{2}$. This dense network may be insufficient to forecast the location of rainfallinduced landslides.

The abundance of landslides in the Sugano area also points to the role of the built up areas in the initiation of the shallow slope failures. It is possible that rainfall falling on the Sugano village was concentrated by surface and sub-surface drainages, by the sewage system, and by local topographic effects. The concentrated water may have resulted in a local increase of infiltration near or at the escarpment, resulting in 
ground instability and slope failures. Due to the morphology of the area, access to the uppermost part of the escarpment was very limited, impossible in places. The limited field surveys have not revealed the presence of pipes or underground channels draining out of the free face of the escarpment. Also, piping effects were not observed in the source areas of the mapped shallow soil slides. Thus, even if we cannot exclude the role of the built up areas in the initiation of landslides, we do not consider it a primary cause of the landslides. This is confirmed by the fact that several landslides occurred $\mathrm{W}$ and $\mathrm{E}$ of Sugano, where built up areas were not present (Fig. 6a).

Despite the fact that many landslides occurred near or in the vicinity of villages, single houses and along the roads, very little information is available on the exact (or even the approximate) time of the slope failures (Table 3). This is surprising, given the distribution of the population in the Orvieto area. Lack of information may be justified by the fact that the most intense rainfall periods occurred during the night. Lack of information on the time of the slope failures prevented us from establishing a rainfall threshold for the initiation of landslides in the Orvieto area. The available, mostly anecdotal, information concurs to establish that the shallow slope failures in the volcanic deposits occurred abruptly, without (apparent) precursory evidence, when rainfall intensity was moderate to high, and when the event cumulative rainfall exceeded $50 \mathrm{~mm}$. The deep seated landslides (e.g., the Badia and Podere Cipresso slide, Figs. 8k, 11a, b) occurred at (and probably after) the end of the main rainfall event (Fig. 9a). This evidence, combined with the fact that the most intense rainfall periods lasted a few hours (from 12 to $20 \mathrm{~h}$, a relatively short period for the existing quantitative rainfall forecasts in central Italy), restricts the possibility of predicting the occurrence of the slope failures based on quantitative rainfall forecasts. Lack of a rainfall threshold for the initiation of landslides also prevents the implementation of a local or regional landslide warning system based on rainfall measurements (i.e., using a network of rain gages), and on estimated (e.g., using meteorological radars) or predicted (e.g., using numerical modelling) rainfall levels. The problem should be considered when determining landslide hazards and risk in the Orvieto area.

The recent rainfall induced landslides in south-western Umbria posed a threat which previously was only partially recognized in the Sugano area (Reichenbach et al., 2005). Due to the complexity of the rainfall induced landslides, most of which were a combination of rapid to extremely rapid failures of several types, defining landslide scenarios and establishing the associated risk was not straightforward. Recognition and proper classification of the existing landslides, including definition of the velocity and types of movement, was essential for a reliable assessment of the expected hazards and the associated risk.

To ascertain landslide risk in the Sugano area we adopted a geomorphological method (Cardinali et al., 2002; Reichen- bach et al., 2005). The method requires the identification of all the existing and past landslides that can be identified in the study area. If individual or multiple landslides are not identified, the frequency and the intensity of the expected landslides may be underestimated. If a landslide type is not recognized, LHZs are not outlined, a specific landslide scenario is not constructed, and landslide risk is not fully ascertained. In the Sugano area, shallow slides and flows originating from volcanic materials were not previously recognized as a dominant landslide type in the area. We attributed the lack of information on shallow slides in the volcanic deposits to the difficulty in recognizing shallow failures that leave subtle morphological evidences, and that are easily concealed by vegetation and human actions. This has negatively affected our ability to fully ascertain landslide hazards and risk in the Sugano area (Reichenbach et al., 2005). The December 2004 rainfall events demonstrated the need for accurate landslide inventories, the usefulness of event inventory maps, and the need for techniques to determine quantitatively the completeness and reliability of landslide inventory maps.

Damage caused by the recent rainfall induced landslides in the Orvieto area, and more specifically, in the Sugano area, allows for considerations on the type, extent and severity of the expected landslide damage in the investigated areas. In the Sugano area, shallow landslides produced: (i) direct functional and structural damage to secondary and farm roads, (ii) direct minor and functional damage to private houses, (iii) indirect damage to private houses, and (iv) indirect damage to the population. No direct damage to people (e.g., death, missing persons, and injured people) was reported. However, direct damage to the population could have occurred. The large rock fall that landed on a farm road $\mathrm{N}$ of Sugano (Fig. 8f) could have produced severe consequences if vehicles or pedestrians were travelling along the road at the time of the failure. The numerous shallow landslides that eroded the volcanic escarpment did not compromise the stability of individual houses, or the safety of their inhabitants, but could have done so if only they were slightly larger or more numerous (e.g., Fig. 11f). In the Orvieto area, soil slide - debris avalanches and debris flows inundated and blocked roads at several localities, causing direct, mostly functional damage to the transportation network, and indirect damage to the population. Again, no direct damage to population was reported, but it could have occurred if one of the several rapid or very rapid landslides had impacted a vehicle travelling along the roads.

\section{Conclusions}

We have examined the type, abundance and distribution of the rainfall induced landslides which occurred in southwestern Umbria as a result of two severe storms in December 2004. Some of the slope failures were typical of the study area (Guzzetti et al., 1996). Typical landslides included 
deep seated and shallow slides and flows in marine deposits, mostly clay and subordinately sand and gravel. Also typical were rock falls originated from the predominant volcanic escarpment present in the study area. Other rainfall induced landslides were less typical. Shallow failures involving volcanic materials and natural and man made debris were previously poorly recognized features. The latter failures started as soil slides and developed into debris avalanches, debris flows, or debris or rock falls, depending on the local morphology.

We have attributed the lack of information on shallow slides in the volcanic weathered materials to the difficulty in recognizing landslides that leave only faint (subtle) morphological evidence, and that are easily concealed by vegetation. The difficult recognition of the landslides and the consequent lack of information resulted in an incomplete - and locally partly incorrect - landslide hazards and risk assessment in the Sugano area. Based on the new evidences, we have updated the risk scenario for extremely rapid landslides, mostly rock falls, and we have introduced a new risk scenario for rapid to very rapid shallow landslides, including soil slides, debris flows and debris avalanches.

Sugano was not the only village in south-western Umbria for which landslide hazards and risk were ascertained (Cardinali et al., 2002; Reichenbach et al., 2005). The assessments prepared for other villages that exhibit the same or similar morphological and lithological setting (i.e., a volcanic mesa capping marine sediments) should be carefully re-examined in view of the new findings. In addition, villages for which the landslide hazards and risk assessments were not originally performed (e.g., Porano), should be examined, and landslide risk systematically ascertained.

Acknowledgements. We acknowledge the collaboration of the Civil Protection Office of Orvieto. We thank S. Peruccacci, M. Rossi and P. C. Stark for help during the field work, and the IRPI hydrology team for providing event and historical rainfall and discharge data. E. E. Brabb reviewed an early draft of the paper. We are grateful to J. L. Zezere and E. Bardou for the constructive reviews and the useful suggestions. Research supported by CNR IRPI and by RISKAWARE, a project partially funded by the EU InterregIIIB CADSES programme. CNR GNDCI publication number 2894.

Edited by: M. Parise

Reviewed by: E. Bardou and J. L. Zezere

\section{References}

Aceto, L., Antronico, L., Gullà, G., Niceforo, D., Scalzo, A., Sorriso-Valvo, M., and Nicoletti, P. G.: Suscettibilità alle colate rapide di fango in alcune aree della Campania, Consiglio Nazionale delle Ricerche, Gruppo Nazionale per la Protezione Idrogeologica,(in Italian), Pubblication n. 2816, Rubettino Industrie Grafiche ed Editoriali, Soneria Mannelli, 38, 2003.

Antonini, G., Ardizzone, F., Cacciano, M., Cardinali, M., Castellani, M., Galli, M., Guzzetti, F., Reichenbach, P., and Sal- vati, P.: Rapporto Conclusivo Protocollo d'Intesa fra la Regione dell'Umbria, Direzione Politiche Territoriali Ambiente e Infrastrutture, (in Italian), ed il CNR-IRPI di Perugia per l'acquisizione di nuove informazioni sui fenomeni franosi nella regione dell'Umbria, la realizzazione di una nuova carta inventario dei movimenti franosi e dei siti colpiti da dissesto, l'individuazione e la perimetrazione delle aree a rischio da frana di particolare rilevanza, e l'aggiornamento delle stime sull'incidenza dei fenomeni di dissesto sul tessuto insediativo, infrastrutturale e produttivo regionale, Unpublished report, May 2002, 140, 2002.

Barla, G., Borri Brunetto, M., and Vai, L.: Un esempio di modellazione matematica in rocce tenere la Rupe di Orvieto,(inItalian), Proc. 3rd Conference on Rock Mechanics and Eng., Technical University, Torino, 14, 1-12, 1990.

Buonasorte, G., Cataldi, R., Ceccarelli, A., Costantini, A., D’Offizi, A., Lazzarotto, A., Ridolfi, A., Baldi, P., Barelli, A., Bestini, G., Bertrami, R., Calamai, A., Camelli, G., Corsi, R., Dacquino, C., Fiordalisi, A., Grezzo, A., and Lovari, F.: Ricerca ed esplorazione nell'area geotermica di Torre Alfina, Lazio-Umbria, (in Italian), Bollettino Società Geologica Italiana, 107, 265-337 , 1988.

Cardinali, M., Reichenbach, P., Guzzetti, F., Ardizzone, F., Antonini, G., Galli, M., Cacciano, M., Castellani, M., and Salvati, P.: A geomorphological approach to estimate landslide hazard and risk in urban and rural areas in Umbria, central Italy, Nat. Hazards Earth Syst. Sci., 2, 57-72, 2002.

Cecere, V. and Lembo-Fazio, A.: Condizioni di sollecitazioni indotte dalla presenza di una placca lapidea su un substrato deformabile, Proceedings 16th National Geotechnical Conference,(in Italian), Bologna, 14-16 May 1986, 1, 191-202, 1986.

Celico, P., Guadagno, F. M., and Vallario, A.: Proposta di un modello interpretativo per lo studio delle frane nei terreni piroclastici, Geologia Applicata e Idrogeologia, (in Italian), 21, 173-193, 1986.

Comune di Orvieto: Emergenza maltempo dell'Orvietano, Dicembre 2004, Written communication, (in Italian), 2005.

Costantini, A., Ghezzo, C., and Lazzarotto, A.: Carta geologica dell' area geotermica di Torre Alfina, in: Ricerca ed esplorazione nell' area geotermica di Torre Alfina, Lazio-Umbria (in Italian), edited by: Buonasorte, G., Bollettino Società Geologica Italiana, 107, 267-337, 1988.

Crosta, G. B. and Dal Negro, P.: Observations and modelling of soil slip-debris flow initiation processes in pyroclastic deposits: the Sarno 1998 event, Nat. Hazards Earth Syst. Sci., 3, 53-69, 2003.

Cruden, D. M. and Varnes, D. J.: Landslide types and processes, in: Landslides, Investigation and Mitigation, edited by: Turner, A. K. and Schuster, R. L., Transportation Research Board, Special Report 247, Washington D. C., 36-75, 1996.

Diamanti, L. and Soccodato, C.: Consolidation of the historical cities of San Leo and Orvieto, Proceedings 10th International Conference on Soil Mechanics and Foundation Engineering, Stockholm, June 1981, 3, 75-82, 1981.

Faraone, D. and Stoppa, F.: Il tufo di Orvieto nel quadro dell'evoluzione vulcano-tettonica della caldera di Bolsena, Monti Vulsini,(in Italian), Bollettino Società Geologica Italiana, 107, 383-397, 1988.

Gazzetta Ufficiale della Repubblica Italiana: Misure urgenti per la prevenzione del rischio idrogeologico ed a favore delle zone col- 
pite da disastri franosi nella regione Campania,(in Italian), Serie Generale, Anno 139, Numero 208, 7 September 1998, 53-74, 1998.

Guadagno, F. M.: Debris flows in the Campanian volcanoclastic soils, Proceedings International Conference Slope Stability Engineering Developments and Applications, Thomas Telford, 125130, 1991.

Guadagno, F. M. and Magaldi, S.: Considerazioni sulle proprietà geotecniche dei suoli allofanici di copertura delle dorsali carbonatiche campane (in Italian), Quaderni di Geologia Appicata, 7, 143-155, 2000.

Guzzetti, F., Cardinali, M., and Reichenbach, P.: The influence of structural setting and lithology on landslide type and pattern, Enviro. Eng. Geosci., 2, 531-555, 1996.

Lembo-Fazio, A., Manfredini, G., Ribacchi, R., and Sciotti, M.: Slope failure and cliff instability in the Orvieto tuff, Proc. 4th Int. Symposium on Landslides, Toronto, 2, 115-120, 1984.

Nappi, G., Chiodi, M., Rossi, S., and Volponi, E.: L'ignimbrite di Orvieto nel quadro dell'evoluzione vulcano-tettonica dei Vulsini orientali, Caratteristiche geologiche e tecniche, (in Italian), Bollettino Società Geologica Italiana, 101, 327-342, 1982.
Nappi, G., Renzulli, A., Santi, P., and Gillot, P. Y.: Geological evolution and geochronology of the Vulsini Volcanic District (Central Italy). Bollettino Società Geologica Italiana, 114, 599-613, 1995.

Reichenbach, P., Galli, M., Cardinali, M., Guzzetti, F., and Ardizzone, F.: Geomorphologic mapping to assess landslide risk: concepts, methods and applications in the Umbria Region of central Italy, in: Landslide risk assessment, edited by: Glade, T., Anderson, M. G., and Crozier, M. J., John Wiley, 429-468, 2005.

Scotto di Santolo, A., Nicotera, M. V., and Ramondini, M.: Analysis of instability phenomena affecting a cut slope in unsaturated pyroclastic soils, in: Landslides in research, theory and practice, edited by: Bromhead, E., Dixon, N., and Ibsen, M. L., Proc. 8th Int. Symposium on Landslides, Cardiff, 1353-1360, 2000.

WP/WLI - International Geotechnical societies' UNESCO Working Party on World Landslide Inventory: A suggested method for reporting a landslide, Int. Assoc. Eng. Geology Bullet., 41, 5-12, 1990. 